\title{
Islamofobia dalam Filem Barat: Analisis Kritis dalam filem American Sniper dan 13 Hours: The Secret Soldiers of Benghazi
}

\section{Islamophobia in Western Films: An Analysis Critics on American Sniper and 13 Hours: The Secret Soldiers of Benghazi}

\author{
Wan Rashidah Hanim Wan Mohamad \\ Department of Da'wah and Human Development, Academy of Islamic Studies, \\ University of Malaya, 50603 Kuala Lumpur, Malaysia.rashidah_apium@siswa.um.edu.my \\ Nor Raudah Siren \\ Department of Da'wah and Human Development, Academy of Islamic Studies, \\ University of Malaya, 50603 Kuala Lumpur, Malaysia.raudah68@um.edu.my
}

DOI: https://doi.org/10.22452/usuluddin.vol48no2.3

\begin{abstract}
Recently, the phobic nature of Islam has gripped Western society called 'Islamophobia'. Islamophobia has existed for so long but has risen over the last decade, after the September 11, 2001, terrorist attack that destroyed the World Trade Center building in New York, USA. Muslim are targeted for their religious ethical and moral beliefs, with the growing tensions of Islamophobia around the world, especially in the West. Additionally, hatred and phobia towards Islam are often expressed through filming. Most of the emergence of this anti-Islamic propaganda film is from the West because the Islamophobic wave itself sparks from the West. Films produced often illustrate the dark side of Islam and Muslim themselves. The film titled American Snipers and 13 Hours: The Secret Soldiers of Benghazi were known to sow the seeds of Islamophobia through the dark side exposure to Islam and adherents such as displaying Arabs as terrorists. These anti-Islamic propaganda films are a problem for the germination of Islamophobia among non-Muslims. Islamophobia is one of the anti-Islam messages. Therefore, this article will identify the Islamophobic messages applied in American Sniper and 13 Hours: The Secret Soldiers of Benghazi. This study also led to a discussion of the Islamic perspective on Islamophobia. The results of the data analysis found that the film studied was a propaganda film that featured anti-Islam propaganda through Islamophobia in the aspect of cinematography and film screenplay whether it was presented clearly or hidden.
\end{abstract}

Keywords: Islamophobia, anti-Islam, film, Hollywood

Abstrak
Mutakhir ini, sifat fobia terhadap Islam telah mencengkam masyarakat
Barat yang disebut sebagai 'Islamofobia'. Islamofobia telah wujud sejak
sekian lama namun ia telah meningkat sejak sedekad yang lalu iaitu
selepas tragedi serangan 11 September 2001 yang memusnahkan 
bangunan World Trade Centre di New York, Amerika Syarikat. Umat Islam sering menjadi sasaran musuh terhadap etika agama dan kepercayaan moral dalam agama Islam ditambah dengan ketegangan yang semakin meningkat saat ini di seluruh dunia terutamanya di Barat. Tambahan lagi, rasa benci dan fobia terhadap Islam sering dizahirkan melalui perfileman. Kebanyakan kemunculan filem propaganda anti-Islam ini adalah dari Barat kerana gelombang Islamofobia itu sendiri tercetus dari Barat. Filem dihasilkan seringkali memaparkan sisi gelap terhadap Islam dan penganutnya. Filem berjudul American Snipers dan 13 Hours: The Secret Soldiers of Benghazi dikenal pasti menyemai benih-benih Islamofobia melalui paparan sisi gelap terhadap Islam dan penganutnya seperti menampilkan masyarakat Arab sebagai teroris. Filem-filem propaganda anti-Islam ini merupakan masalah kepada percambahan rasa Islamofobia di kalangan masyarakat non-muslim. Islamofobia merupakan salah satu daripada mesej anti-Islam. Oleh demikian, artikel ini akan mengidentifikasi mesej Islamofobia yang diaplikasikan dalam filem American Sniper dan 13 Hours: The Secret Soldiers of Benghazi. Kajian ini juga membawa kepada diskusi tentang perspektif Islam terhadap Islamofobia. Hasil analisis data mendapati bahawa filem yang dikaji adalah filem propaganda yang menampilkan propaganda anti-Islam melalui Islamofobia dalam aspek sinematografi dan lakon layar filem sama ada disampaikan secara jelas ataupun tersembunyi.

Kata kunci: Islamofobia, anti-Islam, filem, Hollywood

\section{Pendahuluan}

Sejak kebelakangan ini, umat Islam diseluruh dunia berhadapan dengan isu besar iaitu fenomena Islamofobia terutamanya selepas tragedi 11/9. Di awal pasca tragedi 11/9, Peguam Negara Amerika ketika itu, John Ashcroft mengarahkan ejen Federal Bureau of Investigation (FBI) dan Immigration and Naturalization Services (INS) mempersoalkan individu yang memiliki nama berbunyi Muslim di beberapa kawasan hatta mencari nama-nama mereka menerusi buku telefon. ${ }^{1}$ Fenomena sejak sedekad lalu tidak terhenti begitu sahaja malah terkini, di Amerika Syarikat, Corey Saylor dari Council on American-Islamic Relations mengatakan bahawa jaringan organisasi Islamofobia yang berpusat di Amerika mempunyai sekurang-kurangnya 37 kumpulan yang tujuan utamanya adalah untuk mempromosikan prasangka terhadap Islam

1 Hatem Bazian, "National Entry-Exit Registration System: Arabs Muslims and Southeast Asians and Post-9/11 "Security Measures", Islamophobia Studies Journal, Volume 2-Issue 1, (Spring 2014), 83. 
serta kebencian terhadap Muslim, manakala lebih kurang 32 kumpulan yang lain giat mempromosikan dan menyokong tema Islamofobik. $^{2}$

Amat malang sekali, apabila Amerika Syarikat (AS) sebuah negara yang digelar sebagai negara berkuasa dunia telah melihat agama Islam dan Muslim sebagai ancaman ${ }^{3}$, maka, hal ini membuatkan negara lain yang berkompromi dengan bersandarkan kepada AS turut mempunyai stigma yang sama. Tambahan lagi sikap rasisme dan kebencian berasaskan kaum dan agama di AS sedang meningkat sebagaimana yang dilaporkan oleh The New York Times dalam laporan bertajuk "The Rise of Hate Search" yang diterbitkan pada 12 Disember 2015. ${ }^{4}$ Hal ini juga dapat dibuktikan apabila pimpinan Presiden AS Donald Trump seolah-olah memperluaskan lagi sikap Islamofobia dan Xenophobia dengan membuat beberapa agenda yang jelas menampakkan sikap bencinya terhadap Islam. Antara isunya ialah Trump menghalang orang Islam (Muslim ban) dari tujuh negara iaitu Iraq, Iran, Libya, Somalia, Sudan, Syria, Yaman dari memasuki Amerika. Larangan Trump ini adalah gangguan yang berbahaya dan menunjukkan Islamophobia ini ditaja oleh kerajaan yang mengakibatkan kebakaran dan vandalisme terhadap masjid semakin meningkat, serangan terhadap wanita Muslim yang memakai tudung dan kebangkitan anti-Islam. ${ }^{5}$ Selain di Amerika, tragedi tembakan pengganas bersayap kanan di Masjid Noor, Christchurch New Zealand pada hari jumaat yang mengorbankan 52 nyawa menyayatkan hati segenap umat manusia di dunia. Pengganas sememangnya berniat untuk membunuh umat Islam kerana takut dengan perkembangan agama Islam di Eropah. ${ }^{6}$

2 Corey Saylor, "The U.S. Islamophobia Network: Its Funding and Impact," Islamophobia Studies Journal, Volume 2-Issue 1 (Spring 2014), 100.

3 "Islamofobia Serlah Sikap Perkauman Rakyat Amerika," Berita Harian, 15 Disember 2015, 30.

4 "Islamofobia Serlah Sikap Perkauman Rakyat Amerika," Berita Harian, 15 Disember 2015, 30.

5 Khaled A Beydoun, "How Muslim Ban Incites Vigilante Islamophobic Violence," laman sesawang Al-Jazeera.com, dicapai 12 Mac 2019 http://www .aljazeera.com/indepth/opinion/2017/03/muslim-ban-incites-vigilanteislamophobic-violence-170307065614706.html.

6 Menurut Mohd Mizan Aslam, pengganas ini merupakan warga Australia yang berfahaman radikal Far-Rightwing Extremists dari Neo-Facism atau dikenali juga sebagai Neo-Nazi. selepas perang Dunia Kedua, golongan ini wujud dengan ketara dengan mengambil roh Ketuanan Kulit Putih atau dipanggil 
Gejala Islamofobia ini merupakan salah satu daripada mesej anti-Islam $^{7}$ masa kini. Fenomena ini menyaksikan sikap prejudis, stereotaip dan diskriminasi terhadap umat Islam. Malangnya, terdapat sikap umat Islam sendiri menyumbang rasa fobia barat terhadap Islam di atas beberapa perlakuan yang bertentangan dengan Islam seperti kegiatan keganasan yang menimbulkan rasa stereotaip terhadap Islam. ${ }^{8}$

Selain daripada itu, sifat anti-Islam dan propaganda musuh Islam dilihat melalui kesan yang penting dalam propaganda mereka

\footnotetext{
'White Supremacy'. Golongan ini sangat ekstrem dengan berpaksikan ultranasionalism iaitu mempromosikan kepentingan negara dan bangsa lebih utama dari segalanya, racial-supremacy iaitu kepentingan bangsa atau etnik, authoritarianism iaitu kerajaan autokratik dan menyekat kebebasan berpolitik), nativism iaitu kepentingan politik kaum natif, racial supremacy iaitu kepentingan berasaskan bangsa, populism iaitu memperjuangkan golongan bawahan dan juga menolak imigrasi. Di dalam manisfesto pengganas yang berjumlah 74 muka surat yang dimuat naik sejurus sebelum serangan tersebut jelas menunjukkan dia membenci Islam kerana dianggap imigran yang mengambil tanah tumpah darahnya dan imigran Islam dianggap parasit yang masuk kesemua negara Eropah serta secara perlahan-lahan menjajah negara mereka. Lihat Mohd Mizan Aslam, Bahaya Fahaman Ekstremis Sayap Kanan (Kolumnis Awani), laman sesawang Astro Awani, dikemaskini 19 Mac 2019, dicapai 27 April 2019, http://www.astroawani.com/berita-malaysia/bahayafahaman-ekstremis-sayap-kanan-201602.

7 Islamofobia merupakan salah satu daripada lima mesej anti-Islam yang menurut kajian pengkaji, kelima-lima mesej ini sering dibangkitkan oleh golongan antiIslam iaitu terrorisme, Islamofobia, al-Qur'an, Mohammadisme dan Wanita dalam Islam.

8 Haji Norarfan Haji Zainal menerangkan, "Meninjau situasi masa kini, kedudukan umat Islam semakin ketara amat terancam dan hidup dalam keadaan tidak selesa akibat asakan dan gambaran yang tidak betul terhadap agama Islam dan umatnya. Perlakuan yang tidak Islami yang dilakukan oleh golongan pelampau atas nama agama Islam menuangkan lagi api kemarahan serta menimbulkan prejudis terhadap umat Islam sejagat sehingga Islam dituduh sebagai agama pengganas, pencetus huru-hara, yang akhirnya menjadikan umat Islam sebagai warga minoriti dalam negara bukan Islam dan juga selaku warga dunia dalam situasi terancam, teraniaya dan didiskriminasi. Kini, umat Islam diasak dan diancam dengan ideologi musuh-musuh Islam, iaitu penghapusan umat 'World Without Islam'. Hal ini berlaku kerana stereotaip mereka atas kejadian keganasan yang melibatkan pelaku-pelakunya dari kalangan orangorang Islam tanpa melihat kebenaran dan kesucian ajaran Islam itu sendiri." Lihat Haji Norarfan Haji Zainal, "Perpaduan Ummah: Pengalaman Negara Brunei Darussalam," dalam Perpaduan Ummah Merentasi Ideologi, ed. Asyraf Isyraqi Jamil (Petaling Jaya: Rabitah Antarabangsa Alumni al-Azhar Malaysia, 2015), 47.
} 
iaitu falsafah mereka yang lebih sesuai digambarkan melalui beberapa istilah yang dicipta seperti ektremis, radikal, jihadisme, Muhammadisme, fundamentalisme dan beberapa istilah lain yang ditujukan kepada umat Islam. Oleh itu, falsafah Islamofobia ini salah satu bantuan bagi mencapai misi propaganda anti-Islam mereka kerana sebahagiannya telah diterima oleh masyarakat dunia. Bantuan lebih hebat apabila Barat memanfaatkan legasi Hollywood mereka dengan penghasilan filem-filem Box office yang menyebarkan mesej Islamofobia melalui teknik sinematografi dan lakon layar dalam filem.

Di antara contoh filem Hollywood yang menyebarkan mesej Islamofobia secara tersembunyi ialah filem American Sniper dan 13 Hours: The Secret Soldiers of Benghazi. Filem American Sniper merupakan filem Hollywood yang diarahkan oleh Clint Eastwood dan skripnya ditulis oleh Jason Hall. American Sniper adalah sebuah filem biografi ${ }^{9}$ perang Amerika yang diadaptasikan daripada buku berjudul "American Sniper: The Autobiography of the Most Lethal Sniper in U.S. Military History”. Buku ini merupakan karya mendiang Chris Kyle bersama dengan Scott McEwen dan Jim DeFelice $^{10}$ yang menceritakan tentang kisah benar watak utama, Chris Kyle. Filem aksi ini dilancarkan secara terhad pada 25 Disember 2015 oleh Warner Bros. Pictures di Amerika Syarikat, kemudian mula dilancarkan ke seluruh dunia pada 16 Januari 2015 serta diterjemahkan di dalam pelbagai bahasa. ${ }^{11}$ Filem berdurasi 132 minit ini menelan kos sebanyak 58.8 million dolar Amerika. ${ }^{12}$ Terdapat lima buah syarikat produksi yang terlibat bersama Warner Bros.Pictures dalam pembikinan filem ini iaitu Village Roadshow Pictures, RatPac-Dune Entertainment, Mad Chance Productions, 22

9 Filem biografi atau biopic (singkatan daripada biographical motion picture) adalah sebuah filem yang menjadikan kehidupan seseorang tokoh sebagai kisah benar di mana nama bagi watak tersebut digunakan. Rujuk: http://muse.jhu.edu /journals/abs/summary/v024/24.1.bastin.html. Lihat juga bacaan penuh buku (format pdf) berjudul American Sniper: The Autobiography of the Most Lethal Sniper in U.S. Military History karya Chris Kyle di pautan http://elibrary.bsu.az /books_163/N_20.pdf.

10 “American Sniper (2014)," laman sesawang IMDB, dicapai 3 Januari 2019, http://www.imdb.com/title/tt2179136/awards.

11 “American Sniper," dicapai 22 Mac 2019, http://www.allmovie.com/movie /american-sniper-v581791/cast-crew.

12 “American Sniper," dikemaskini 2 Januari 2016, dicapai 14 Januari 2019, http://www.boxofficemojo.com/movies/?page=main\&id=americansniper.htm. 
\& Indiana Pictures dan Malpaso Productions. ${ }^{13}$ Penggambaran filem American Sniper dijalankan di negara Maghribi selama 11 hari iaitu pada bulan April 2014. ${ }^{14}$

Filem ini mengandungi tema yang berunsur aksi, drama dan perang dan sub-genre berunsur biografi (biopic) bersama dengan drama perang. Namun begitu, tema yang awal dan utama yang ditemui ialah tema heroisme. Tema ini diangkat sebagai tema utama kerana di awal babak sudah menunjukkan aksi Chris Kyle menembak dari atas bangunan. Tema heroisme juga disadur dari ketokohan Chris Kyle menerusi buku biografi tulisan mendiang yang berjudul "The Autobiography of the Most Lethal Sniper in US Military History". Selain mengandungi genre utama yang berunsur aksi heroisme dan kekeluargaan, sub-genre berunsur biografi (biopic) bersama dengan drama perang juga dijadikan tema dalam filem ini. ${ }^{15}$

Secara jelas, filem American Sniper ditemakan dari persoalan "perang melawan terorisme". Jika dilihat dari babak awal sudah menunjukkan aksi latihan ketenteraan bagi melawan teroris. Kenyataan ini juga disokong dengan sebuah dialog yang mengatakan "I came here to kill terrorists" yang ditujukan kepada orang Islam. Seperti ditulis di atas, penulis mendapati persoalan utama yang cuba digarapkan oleh penerbit filem adalah "perang melawan terrorisme". Terrorisme merujuk kepada aktiviti keganasan orang Islam, dengan sedemikian, mesej Islamofobia disampaikan melalui filem ini. Hal ini dapat disabitkan dengan persembahan dalam filem yang seringkali memaparkan aktiviti terrorisme oleh orang Islam, sebagai contoh serangan letupan yang

13 "American Sniper (2014): Company Credit," dicapai 14 Januari 2019, http://www.imdb.com/title/tt2179136/companycredits?ref_=ttpl_ql_dt_5

14 Sepanjang penggambaran di Maghribi, segala peralatan ketenteraan dan askar tambahan dibekalkan oleh kerajaan Amerika. Sebahagian besar filem itu difilemkan di California, di sebuah padang set penggambaran di Blue Cloud, Santa Clarita dan di lokasi padang pasir di sekitar El Centro yang juga mengambil masa selama 11 hari. Filem American Sniper boleh juga diklasifikasikan sebagai filem yang membawa fenomena ketika dilancarkan disebabkan oleh jumlah penonton yang luar biasa. Lihat Alex Ben Block, "The Making of 'American Sniper': How an Unlikely Friendship Kickstarted the Clint Eastwood Film," laman sesawang HOLLYWOOD REPORTER, dicapai 22 Mac 2019, https://www.hollywoodreporter.com/news/making-american-sniper-how -an-760963.

15 “American Sniper," dicapai 22 Mac 2019, http://www.allmovie.com. 
telah memusnahkan kedutaan Amerika di Dar Es Salaam, Tanzania dan Nairobi di Kenya yang dikatakan oleh CNN sebagai agenda perang musuh untuk menentang Amerika (minit 9:40). Selain itu, figura pengganas Muslim sering ditonjolkan sebagai bangsa Arab, berjanggut panjang, berserban dan memegang senapang (minit 29:51). Begitu juga, filem ini memaparkan visual tragedi 11/9 di televisyen menerusi siaran berita CNN (minit 22:16).

Seterusnya, filem 13 Hours: The Secret Soldier of Benghazi berasal dari buku berjudul 13 Hours: The Inside Account of What Really Happened in Benghazi hasil tulisan Mitchell Zuckoff dan kumpulan pegawai keselamatan Annex yang menampilkan garapan kisah benar berkisarkan tentang serangan ke atas kompaun Amerika Syarikat di Libya dan perjuangan pasukan keselamatan dalam menghadapi kekacauan itu. Filem 13 Hours diterbitkan pada 15 Januari 2016 di Amerika Syarikat. Filem berdurasi dua jam 24 minit ini diarahkan oleh Michael Bay manakala skrip lakon layar ditulis oleh Chuck Hogan. ${ }^{16}$ Filem ini dikeluarkan oleh syarikat penerbitan filem terkenal, Paramount Pictures dengan kerjasama syarikat 3 Arts Entertainment dan Platinum Dunes. Filem ini telah menelan belanja sebanyak 50 juta dolar Amerika. ${ }^{17}$ Secara ringkasnya, filem ini mengisahkan tentang enam anggota pasukan bekas tentera elit yang telah dipanggil untuk melindungi kompleks konsulat Amerika Syarikat di Benghazi.

Filem 13 Hours: The Secret Soldiers of Benghazi merupakan filem yang mengangkat tema dari kisah benar atau biografi yang berlaku di Benghazi, Libya ketika serangan pengganas pada ulang tahun peristiwa 11 September iaitu pada 11 September 2012. Seperti filem American Sniper yang mengemukakan tema secara jelas dan tersirat, filem 13 Hours: The Secret Soldiers of Benghazi juga tidak terkecuali menampilkan beberapa tema yang wujud sebagai unsur yang penting sebagai fokus dan dasar pengarah filem dalam mengembangkan jalan cerita. Filem 13 Hours mengandungi tema yang berunsur sejarah, heroisme dan thriller (mencemaskan) dan perang namun mempunyai pelbagai mesej yang rumit dan

16 “13 Hours (2016)," laman sesawang IMDB, dicapai 22 Mac 2019, https://www .imdb.com/title/tt4172430/.

17 "13 Hour: The Secret Soldier of Benghazi," laman sesawang Movies Wikia, dicapai 27 Mac 2019, http://movies.wikia.com/wiki/13_Hours:_The_Secret _Soldiers_of_Benghazi. 
kompleks. Pengkaji mendapati pengarah mengangkat tema politik (sejarah) sebagai tema utama dalam filem ini. Tema ini diangkat sebagai tema utama kerana pada prolog awal filem sudah mencatatkan tentang Libya yang dinamakan sebagai salah satu tempat paling berbahaya di dunia yang menyaksikan penarikan pejabat-pejabat diplomatik oleh negara lain kerana takut serangan oleh militan. Terdapat juga paparan visual sebenar Muammar Gaddafi di era pemerintahannya sehingga digulingkan oleh kumpulan pemberontak sehingga dibunuh.

Selain itu, tema heroisme juga ditemui apabila Amerika ditonjolkan sebagai hero dengan penempatan markas CIA di negara Libya yang sedang bergolak. Begitu juga aksi heroisme menerusi persembahan pertahanan oleh enam orang anggota pasukan GRS iaitu Rone, Jack, Oz, Tig, Tanto dan Boon. Pasukan anggota GRS ini ditonjolkan sebagai anggota yang sanggup mempertaruhkan nyawa demi menyelamatkan rakyat mereka.

Begitu juga tema thriller iaitu tema yang mencemaskan turut ditampilkan menerusi babak getir ketika mereka berhadapan dengan musuh. Tema ini melibatkan kejahatan, keganasan oleh pengganas terhadap rakyat Amerika sebagai mangsa. Di dalam filem ini, kumpulan militan Islam ditonjolkan sebagai musuh Amerika. Tema thriller dipaparkan menerusi beberapa babak cemas seperti ketika kumpulan pemberontak Islam menuang diesel untuk membakar kompaun Duta dan mengepung mangsa, Duta bersama pegawai keselamatannya Scott dan pegawai teknologi maklumat Sean Smith berada dalam situasi cemas untuk menyelamatkan diri. Paparan kekejaman yang dilakukan oleh orang Islam mencipta Islamofobia dalam filem.

\section{Konsep Islamofobia}

Sejarah menceritakan penggunaan istilah Islamofobia mula digunakan di awal abad ke-20 dan muncul sebagai sebuah perkataan baru (neologism) pada tahun 1970, kemudian menjadi semakin penting sekitar tahun 1980 -an dan 1990 -an, ${ }^{18}$ serta menjadi semakin

18 Nasar Meer dan Tariq Modood, Refutations of Racism in the 'Muslim Question dalam "Anti-Muslim Prejudice in the West, Past and Present," Journal Patterns of Prejudice, Volume 43 (2009), 340. Lihat juga Junaid Rana, "The Story of Islamophobia," Souls: A Critical Journal of Black Politics, Culture, and Society, vol. 9, no.2, (2007), 148-62, (149). 
popular selepas serangan 11 September 2001. Pada tahun 1996, Suruhanjaya Muslim British dan Islamophobia telah melancarkan istilah Islamofobia, seterusnya, pada tahun 1997 penggunaan istilah Islamofobia mula diperkenalkan melalui sebuah laporan yang dikeluarkan oleh suruhanjaya tersebut iaitu Runnymede ${ }^{19}$ Trust Report Islamophobia ${ }^{20}$. Makna Islamofobia diukur melalui dua aspek yang berbeza iaitu pertama, dari sudut pandangan protagonist (pelaku) Islamofobia dan dari sudut pandangan mangsa Islamofobia. ${ }^{21}$

Di dalam laporan Badan Peninjau Islamofobia OIC Mei 2007Mac 2008 (OIC Observatory Report on Islamophobia) menulis bahawa menurut pentakrifan kamus, phobia dari segi terminologi ditakrifkan sebagai ketakutan atau kebencian yang keterlaluan. ${ }^{22}$ Manakala, Islamofobia pula didefinisikan sebagai ketakutan tidak rasional atau amat kuat atau kebencian terhadap Islam. ${ }^{23}$ Pelapor Khas Pertubuhan Bangsa-Bangsa Bersatu (PBB), Doudou Diene mendefinisikan Islamofobia sebagai suatu permusuhan dan ketakutan tidak berasas terhadap Islam atau sebagai kesan daripada perasaan takut dan benci terhadap orang Islam atau majoriti daripada mereka. ${ }^{24} \mathrm{Hal}$ ini dapat dilihat dari signifikasi istilah

19 The Runnymede Trust, "Islamophobia a Challenge for Us All", laman sesawang RunnymedeTrust, dicapai 15 April 2019, http://www.runnymedetrust.org /uploads/publications/pdfs/islamophobia.pdf.

20 Fateh Uenal, "Disentangling Islamophobia: The Differential Effects of Symbolics, Realistic, and Terroristic Threat Perceptions as Mediators Between Social Dominance Orientation and Islamophobia,"Journal of Social and Political Psychology, Vol.4 (1) (2016), 6.

21 Ekmeleddin Ihsanoglu, "1 ${ }^{\text {st }}$ OIC Observatory Report on Islamophobia" (laporan, $35^{\text {th }}$ Session of the Council of Foreign Ministers (May 2007- March 2008), Jeddah, 9.

22 Ekmeleddin Ihsanoglu, "1 ${ }^{\text {st }}$ OIC Observatory Report on Islamophobia”, 8.

23 Ihsanoglu, "1 ${ }^{\text {st }}$ OIC Observatory Report on Islamophobia", 8.

24 Darara Timotewos Gubo, Blasphemy and Defamation of Religions in a Polarized World: How Religious Fundamentalism Is Challenging Fundamental Human Rights (Lexington Books: London, 2015), 62. Doudou Diene mengeluarkan definisi Islamofobia ini di dalam laporannya kepada Sesi Ke-6 Majlis Hak Asasi Manusia ( $6^{\text {th }}$ Session of the UN Human Right Council) tentang fitnah terhadap agama dan secara khususnya kesan serius dari Islamofobia yang merencatkan kebebasan menikmati hak-hak asasi. Diene merupakan Pelapor Khas PBB (UN Special Rapporteur) bagi Bahagian Hal Ehwal Kontemporari bagi Isu Rasisme, Diskriminasi Etnik, Xenophobia dan Sikap Tidak Bertoleransi (Contemporary Forms of Racism, Racial Discrimination, Xenophobia and Related Intolerance). 
'fobia' yang memberi impak efektif menerusi penjenamaan istilah tersebut.

Justeru itu, dalam makalah ini pengkaji akan mengkaji mesej Islamofobia melalui tiga elemen Islamofobia iaitu sikap terhadap Islam \& Muslim (Prejudis, Stereotaip, Diskriminasi), ketakutan yang tidak berasas dan yang terakhir, kebencian yang keterlaluan yang diaplikasikan dalam filem yang dikaji. ${ }^{25}$ Tiga elemen Islamofobia adalah seperti berikut:

1. Sikap Prejudis, Stereotaip dan Diskriminasi Terhadap Umat Islam.

Pada tahun 1997, Commission on British Muslims and Islamophobia melancarkan Laporan Runnymede Trust bertajuk Islamophobia: a Challenge for All of Us yang mengeluarkan perkataan Islamofobia dengan memberi maksud "prejudice vis-àvis Muslims" (prasangka terhadap orang Islam). ${ }^{26}$ Islamofobia secara harfiah bermaksud tidak masuk akal dan ketakutan yang tidak wajar terhadap Islam. ${ }^{27}$ Intipati prejudis terhadap orang Islam ini merangkumi komponen yang melihat agama Islam sebagai musuh monolitik, statik dan tidak bertindak balas untuk berubah serta Islam dilihat sebagai "lemah" kepada Barat. Selain itu juga, pandangan stereotaip bahawa Islam dilihat sebagai tidak rasional dan primitif. Bahkan juga permusuhan terhadap Islam digunakan untuk membenarkan amalan diskriminasi terhadap umat Islam dan pengecualian umat Islam dari masyarakat arus perdana sehingga mengakibatkan perasaan anti-Muslim dilihat sebagai neutral atau sesuatu yang normal. ${ }^{28}$ Islamofobia juga memberi kesan praktikal dari permusuhan iaitu dari segi diskriminasi, prejudis, dan hak yang tidak sama rata yang mana umat Islam sama ada individu atau masyarakat menjadi mangsa dan pengecualian mereka dari bidang politik serta ruang lingkup sosial. Istilah Islamofobia dicipta sebagai tindak balas kepada realiti baru iaitu peningkatan diskriminasi terhadap umat Islam yang telah muncul sejak

25 Tiga elemen Islamofobia ini adalah dari garapan model susunan OIC Observatory Report on Islamophobia yang dikeluarkan pada Mei 2007 sehingga Mac 2008. Lihat pautan: http://ww1.oic-oci.org/uploads/file /Islamphobia/islamphobia_rep_may_07_08.pdf

26 Ihsanoglu, "1 1 st OIC Observatory Report on Islamophobia", 9.

27 Ihsanoglu, " 1 st OIC Observatory Report on Islamophobia", 9.

28 Ihsanoglu, "1 1 st OIC Observatory Report on Islamophobia", 9. 
kebelakangan ini. Sebagai contoh, diskriminasi dalam pekerjaan terhadap orang Islam di Amerika, terutamanya selepas serangan 9/11 dan perang di Iraq dan Afghanistan. ${ }^{29}$

\section{Ketakutan yang Tidak Berasas}

Agama Islam yang ditakuti atau sinonim sebagai menakutkan bukanlah agama yang baru muncul dari ajaran individu tertentu, bahkan juga bukan ajaran agama yang tiada dalam rekod sejarah. ${ }^{30}$ Hakikatnya, Islam adalah agama yang wujud sejak hampir seribu lima ratus tahun dahulu dan mengajar manusia nilai akhlak dan ketuhanan yang menjamin keamanan hidup manusia. Secara literalnya juga Islam bermaksud keselamatan dan kesejahteraan. Malangnya, Islam menjadi agama yang harus ditakuti ${ }^{31}$ kesan dari agenda Islamofobia Barat terutamanya dari aktiviti ekstremisme pelampau Muslim. Menurut John Esposito, Islamophobia adalah ketika anda memiliki ketakutan yang tidak berasas, yang memberi maksud bahawa orang mesti takut terhadap ekstremisme Islam. ${ }^{32}$ John berpendapat, hakikatnya para mangsa utama pelampau Muslim adalah sejumlah besar orang yang hidup di dunia Islam. Menurut beliau, realitinya itulah ketakutan yang munasabah. Demikian juga menyamakan agama (Islam) dan kebanyakan pengikutnya di atas kesilapan tertentu. Namun, John berpandangan bahawa setiap agama mempunyai sisi gelapnya serta orang yang menyalahgunakannya dengan terlibat dalam keganasan. ${ }^{33}$ Secara

29 Kevin L. Nadal et al., "Subtle and Overt Forms of Islamophobia: Microaggressions toward Muslim Americans", Journal of Muslim Mental Health, Vol. 6, Issue 2, (2012), 16.

${ }^{30}$ Mohd. Farid bin Mohd Shahran, "Islamofobia: Mengubah Ketakutan kepada Penghormatan", laman sesawang IKIM, dicapai 10 Disember 2019, http://www.ikim.gov.my/new-wp/index.php/2019/12/06/islamofobiamengubah-ketakutan-kepada-penghormatan-2/.

31 Mohd. Farid bin Mohd Shahran, "Islamofobia: Mengubah Ketakutan kepada Penghormatan", laman sesawang IKIM, dicapai 10 Disember 2019, http://www .ikim.gov.my/new-wp/index.php/2019/12/06/islamofobia-mengubah-ketakutan -kepada-penghormatan-2/.

32 Carla Hinton, "Q\&A with Islamic Studies Scholar John L. Esposito", laman sesawang Oklahoman.com, dicapai 10 Disember 2019, https://oklahoman.com /article/3954360/qa-with-islamic-studies-scholar-john-l-esposito?.

33 Carla Hinton, "Q\&A with Islamic Studies Scholar John L. Esposito", laman sesawang Oklahoman.com, dicapai 10 Disember 2019, https://oklahoman.com /article/3954360/qa-with-islamic-studies-scholar-john-l-esposito?. 
ringkasnya, ketakutan yang tidak rasional ini sangat hebat dan berperasaan seolah-olah umat Islam berada di bawah pengepungan dan serangan. ${ }^{34}$

\section{Kebencian yang Keterlaluan}

Menurut Lathifah Ibrahim Khadhar dalam bukunya "Ketika Barat Memfitnah Islam", kebencian kepada Islam itu sudah ada sejak lama. Kebencian itu sudah muncul sejak permulaan dakwah, bahkan sebelum lahirnya dakwah kerana Islam telah disebut dalam kitab-kitab agama sebelum Al-Qur'an lagi. ${ }^{35}$ Fenomena Islamofobia dalam intinya adalah kebencian berasaskan agama. ${ }^{36}$ Islamofobia biasanya berlaku kepada masyarakat atau seseorang yang kurang pengetahuan agamanya kerana mereka telah dipengaruhi oleh kebebasan, liberalisme serta kekurangan ilmu ajaran Islam yang sebenar. Selain daripada kejahilan mengenai makna sebenar dan ajaran Islam, punca berlaku kebencian yang keterlaluan adalah kerana sikap fanatik beragama sebagaimana Kristian dan Yahudi yang membenci Islam sejak dahulu lagi. ${ }^{37} \mathrm{Di}$ Barat, kebencian terhadap Islam atau Muslim berkembang luas di tengah retorik kebencian serta keganasan yang semakin meningkat dalam gejala Islamofobia. Sebagai contoh, sebuah tinjauan USA TODAY mendapati bahawa hampir satu perempat rakyat Amerika, sebanyak $22 \%$ mengatakan tidak ingin berjiran dengan orang Islam. $^{38}$

\section{Analisis Mesej Islamofobia dalam Filem}

Analisis dalam bahagian ini bukan hanya spesifik kepada rasa 'fobia' sahaja, namun pengkaji menganalisis tiga elemen Islamofobia iaitu tiga cabang sikap terhadap Islam \& Muslim (Prejudis, Stereotaip, Diskriminasi), ketakutan yang tidak berasas dan yang terakhir, kebencian yang keterlaluan. Berikut merupakan jadual analisis sebagai persembahan yang lebih jelas:

${ }^{34}$ Ihsanoglu, "1 1 st OIC Observatory Report on Islamophobia", 8.

35 Lathifah Ibrahim Khadhar, Ketika Barat Memfitnah Islam, terj. Abdul Hayyie Alkattani (Jakarta: Gema Insani Press, 2005), 59.

36 Ihsanoglu, "1 ${ }^{\text {st }}$ OIC Observatory Report on Islamophobia", 8.

37 Abdul Aziz, "Menangkal Islamofobia melalui Re-Interpretasi Al-Quran," Jurnal Pemikiran Islam dan Filsafat (Al-A'raf), Vol 13, No 1 (2016), 71.

38 John L. Esposito dan Dalia Mogahed, Who Speaks For Islam?: What a Billion Muslims Really Think (New York: Gallup Press, 2007), ix. 


\begin{tabular}{|c|c|c|}
\hline Mesej Islamofobia & American Sniper & 13 Hours \\
\hline $\begin{array}{l}3 \text { sikap terhadap } \\
\text { Islam dan Muslim } \\
\text { (prejudis, stereotaip } \\
\text { dan diskriminasi) }\end{array}$ & $\begin{array}{l}\text { Kanak-kanak Islam } \\
\text { terdedah dengan } \\
\text { aktiviti keganasan } \\
\text { sejak kecil. }\end{array}$ & $\begin{array}{l}\text { Kebanyakan } \\
\text { Muslim adalah } \\
\text { orang jahat. }\end{array}$ \\
\hline $\begin{array}{ll}\text { Ketakutan } & \text { yang } \\
\text { tidak berasas } & \end{array}$ & $\begin{array}{lr}\text { Panorama } & \text { Iraq } \\
\text { sebagai } & \text { sebuah } \\
\text { negara perang yang } \\
\text { menakutkan. }\end{array}$ & $\begin{array}{lr}\text { Mengklasifikasikan } \\
\text { Libya rebagai } \\
\text { negara paling } \\
\text { berbahaya di dunia. }\end{array}$ \\
\hline $\begin{array}{l}\text { Kebencian } \\
\text { keterlaluan }\end{array}$ & $\begin{array}{ll}\text { Dendam } & \text { kesumat } \\
\text { Chris } & \text { terhadap } \\
\text { Islam. } & \\
\end{array}$ & $\begin{array}{lr}\text { Benci } & \text { terhadap } \\
\text { azan dan umat } \\
\text { Islam. }\end{array}$ \\
\hline
\end{tabular}

Jadual 1: Mesej Islamofobia dalam

filem American Sniper dan 13 Hours

1. Sikap Prejudis, Stereotaip dan Diskriminasi Terhadap Islam dan Penganutnya

Mesej Islamofobia di dalam filem American Sniper menerusi rasa prejudis, stereotaip dan diskriminasi terhadap Islam dikesan dalam beberapa babak. Di antaranya, pada minit ke 03:05 apabila seorang kanak-kanak diberi bom tangan oleh seorang wanita Iraq untuk dibaling ke arah askar Amerika.

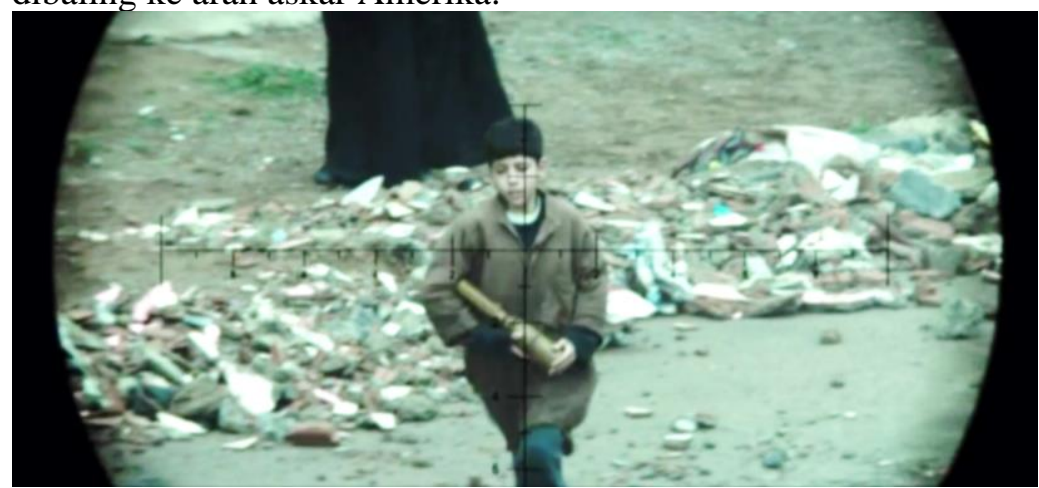

Rajah a i: Kanak-kanak Iraq membaling bom RPG ke arah askar Amerika.

Babak ini menunjukkan keberanian kanak-kanak kecil tersebut memegang senjata merbahaya dan seolah-olah sudah biasa melakukan sedemikian. Fenomena seperti ini boleh mencipta rasa prejudis terhadap Islam kerana kononnya mendedahkan kanak- 
kanak dalam aktiviti keganasan. Selain daripada shot yang ditayangkan, dialog "evil" yang diucapkan oleh Chris juga membawa mesej stereotaip terhadap orang Islam. ${ }^{39}$

Sementara itu, minit ke 25:33 dan 1:03:08 juga menunjukkan sikap prejudis Marc Lee dengan mengatakan secara umumnya bahawa lelaki yang seusia tentera yang masih kekal di kawasan evakuasi merupakan pengganas.

"Marc Lee: Any military-age male who is still here is here to kill you."

Mesej sebegini disampaikan dengan memukul rata lelaki Muslim seusia askar Amerika yang dianggap sebagai pengganas sedangkan hakikatnya terdapat dari kalangan mereka adalah mangsa yang tidak bersalah. Hal ini disebut sebagai signature strikes, ${ }^{40}$

Sementara itu, ketika Chris (minit 41:37) menyertai pasukan askar Marin menyerbu sebuah rumah, Sanchez seorang anggota Marin menunjukkan rasa prasangka terhadap Sheikh al-Obeidi dengan mengatakan al-Obeidi akan meletupkan mereka sebaik sahaja mereka masuk.

"Sanchez: No. This Hajji just wants us all in here so he can blow us up. Go check his ass for a vest."

Prasangka ini terbukti salah kerana Obeidi tidak ditonjolkan sebagai orang awam yang memiliki senjata. Seterusnya, minit ke 01:04:59 menunjukkan sikap prejudis Chris terhadap tuan rumah warga Iraq apabila memperlihatkan sikunya yang hitam ketika mengambil buku anaknya yang jatuh ke lantai. Tanda 'shooters strawberries' (tanda hitam pada siku kesan daripada kerap menembak) yang dilihat oleh Chris ini terus membuatkannya

39 Chris mengungkapkan, "There was a kid who...barely had any hair on his balls. Mother gives him a grenade, sends him out here to kill marines. Dude, that's evil like I never seen before".

40 'Signature strikes' bermaksud mensasarkan orang yang tingkah laku mereka dinilai mirip dengan pengganas dan menjadi sasaran untuk dibunuh. Kumpulan hak asasi manusia telah lama mengecam amalan ini kerana pembunuhan yang samar-samar dengan mensasarkan "any military-age male" di kawasan pengganas beroperasi. Pembunuhan yang disasarkan ini sebagai pembunuhan tanpa nama (anonymous killing). Lihat pautan ini: Spencer Ackerman, "US To Continue 'Signature Strikes' on People Suspected of Terrorist Links", laman sesawang The Guardian, dicapai 10 Disember 2019, https://www.theguardian.com/us-news/2016/jul/01/obama-continue-signaturestrikes-drones-civilian-deaths. 
berhenti makan secara tiba-tiba dan terus mencari bukti bahawa tuan rumah terbabit adalah seorang pengganas.

Babak seterusnya membuktikan bahawa tuan rumah terbabit dengan aktiviti keganasan apabila Chris menjumpai pelbagai jenis senjata api di rumah lelaki tersebut (minit 1:06:24).

Selain itu, di dalam Trip 3 ke Iraq, iaitu pada minit ke 01:18:04, Biggles memaklumkan kepada Chris bahawa dia sudah membeli cincin tunang untuk teman wanitanya. Biggles membelinya di Iraq, dan Chris meragui keaslian cincin tersebut dan menyebut kemungkinan cincin itu dari "blood diamond" (berlian berdarah).

Chris: Dude, you bought it from savages?

How do you know it's not a blood diamond?

Pertanyaan dan nada intonasi suara Chris menyuarakan rasa prejudis terhadap berlian di Iraq kerana blood diamond merupakan berlian yang dijual untuk membiayai pemberontak yang kebanyakannya diambil di zon Afrika sehingga mengakibatkan kehilangan banyak nyawa. ${ }^{41}$

Filem 13 Hours pula, pada babak pembukaan filem lagi iaitu pada minit ke 3:50 telah menampilkan pandangan tajam orangorang Islam yang memandang Jack ketika beliau baru mendarat di Lapangan Terbang Benina, Benghazi menaiki pesawat awam yang majoriti penumpangnya beragama Islam dari sosok penampilan mereka. Pandangan dan jelingan askar awam yang bersenjata mengawal sekitar lapangan terbang juga menakutkan. Keadaan itu diikuti pula dengan sound effect heart-beat yang mendebarkan serta panorama suasana negara perang yang tidak aman. Jack berjalan penuh berhati-hati ditengah-tengah orang Islam yang berpakaian tradisional seperti berjubah dan berserban. Babak ini berjaya memberi gambaran prejudis bahawa Muslim bersikap antiAmerika.

Demikian juga, aksi Tyrone yang menjemput Jack di lapangan terbang berjalan sambil matanya memerhatikan kiri dan kanan berjaya membawa rasa berdebar di hati penonton. Jelingan 'AWAS' oleh Tyrone cukup menunjukkan keadaan tidak selamat dan serangan boleh berlaku pada bila-bila masa di lapangan terbang tersebut. Selain itu, Tyrone juga membekalkan pistol kepada Jack dan menyerahkannya sebaik mereka memasuki jip. Di awal babak

41 Levy Arnaldo dan Bohari Muslim, Ragam Pesona Batu Nusantara (Jakarta: Wahyumedia, 2015), 2. 
filem juga (minit ke 6:00) menunjukkan suasana tegang apabila orang Islam bergaduh dengan jeritan suara wanita dan kanak-kanak sehinggakan mengakibatkan seorang terbunuh.

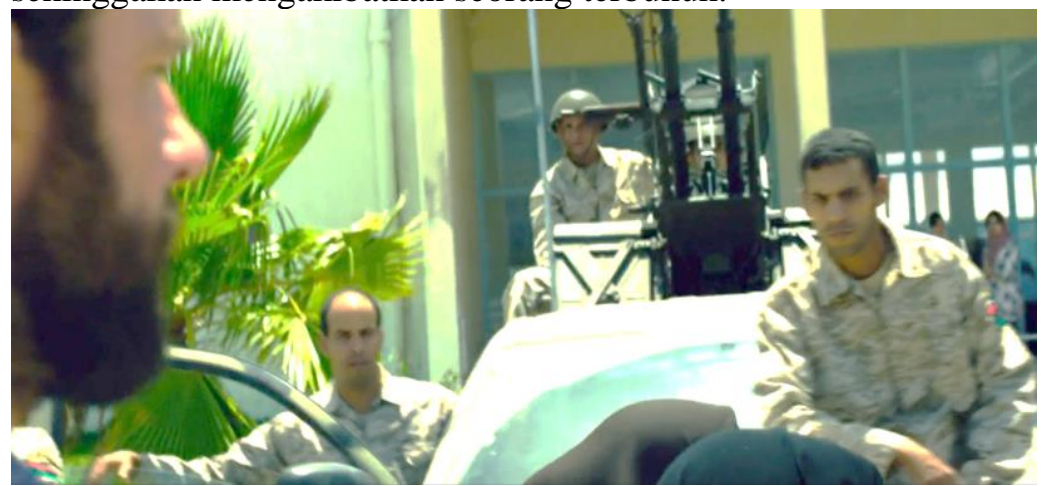

Rajah a ii: Polis Libya dan orang awam memandang Jack dengan pandangan yang tajam ketika beliau baru mendarat di Lapangan Terbang Benina, Libya.

Ironinya, situasi yang digambarkan di dalam filem ini boleh memberi kesan negatif kepada penonton seperti mencipta rasa stereotaip, takut kepada Islam dan tidak selamat serta rasa terasing apabila bersendirian di dalam kelompok orang Islam yang berpenampilan jubah dan serban yang kesemuanya memerhati dengan pandangan tajam dan liar.

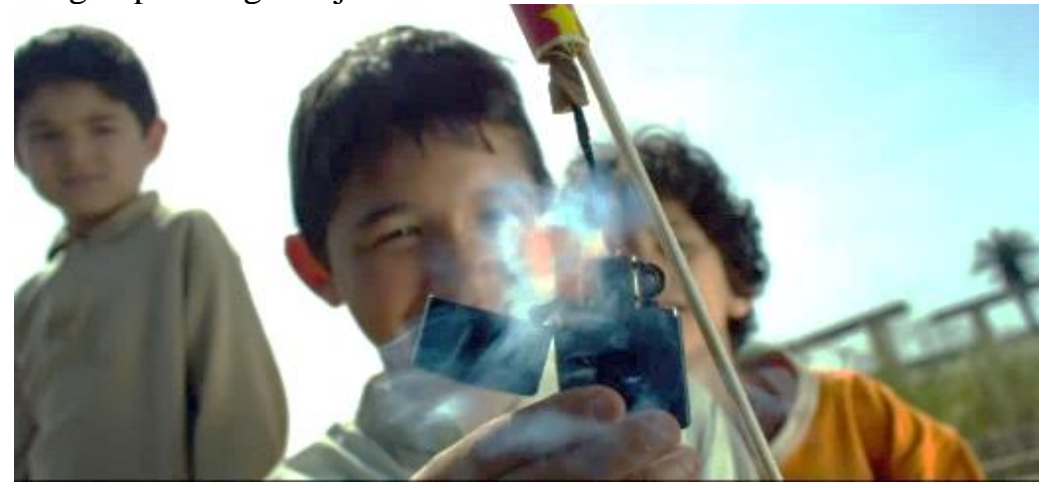

Rajah a iii: Sekumpulan kanak-kanak melepaskan mercun ke arah pasukan askar Amerika.

Selain itu, seperti babak dalam American Sniper yang mempamerkan kanak-kanak terlibat dengan aktiviti keganasan, filem 13 Hours: The Secret Soldiers of Benghazi juga apabila minit ke 13:29 menunjukkan tiga orang kanak-kanak yang meletuskan 
mercun ke arah pasukan askar AS. Selepas itu, mereka berlari ke arah tiga orang lelaki dewasa pengganas lantas dipeluk mereka kerana patuh dengan arahan mereka untuk berbuat demikian.

Manakala, ketika Jack berada di dalam pejabat Ketua, Ketua bertanyakan satu soalan tentang mengapa tidak memakai cincin kahwin lalu Jack memberikan jawapan (minit ke 14:34) berunsur strereotaip terhadap Muslim yang berkemungkinan akan menggunakan cincin mereka. Seterusnya ketika Duta AS, Chris Stevens berada di dalam majlis perjumpaan tertutup di Pejabat Datuk Bandar (minit ke 32:18), Jack melahirkan rasa sangsi terhadap orang Islam dengan mengatakan kemungkinan letupan bunuh diri boleh terjadi;

Jack: Any one of these people could klack off a vest.

Jack berasa prejudis terhadap serangan berterusan yang dilakukan oleh militan Islam pada minit ke 54:27:

Jack: Chief, think. You let them take that consulate, where do you think the next target's gonna be?

Ketika kumpulan CIA berada di saat getir pertempuran, Boon melahirkan perasaan syak wasangka (minit ke 58:48) terhadap tentera Libya supaya mereka tidak ditembak secara senyap.

Boon: Just don't shoot us in the back

Seterusnya, dialog pada minit ke 1:28:59 menunjukkan rasa prejudis Tanto terhadap masyarakat Libya.

Tanto: They're all bad guys until they're not.

Seperti babak sebelum ini (minit ke 18:38) yang menunjukkan senjata api di jual di pasar Bandar Benghazi secara bebas tanpa kawalan, Tyrone menerusi suatu dialog bersama anggota CIA yang lain memperakui hal tersebut pada minit ke 1:29:32. 'Everyone' merujuk kepada semua rakyat Libya dan sikap prejudis seperti ini tidak dapat dihakis dek kerana kewujudan pasar senjata api tersebut yang menyebabkan prasangka wujud terhadap masyarakat Benghazi.

Tyrone: Everyone's got weapons in Benghazi. Until you see a weapon in someone's hands, you do not fire.

Di saat Ketua memaklumkan kepada Tyrone tentang pengesahan daripada hospital Benghazi bahawa Duta AS dibawa hidup-hidup ketika insiden serangan, Tyrone membalas pada minit ke 1:38:21 dengan mengatakan kemungkinan itu hanyalah perangkap kepada mereka. 
Tyrone: Could try and draw us in. Watch out for an ambush.

Sikap prejudis, stereotaip dan diskriminasi terhadap Islam dan penganutnya dapat dilihat dalam beberapa babak sama ada dari aspek lakon layar filem mahupun aspek sinematografi. Aspek lakon layar lebih banyak ditemui di dalam kedua-dua filem berdasarkan dialog dan teks yang mempunyai unsur prejudis dan stretrotaip berbanding aspek sinematografi yang hanya sedikit seperti shot kanak-kanak yang melakukan aktiviti keganasan.

\section{Ketakutan yang Tidak Berasas}

Pengkaji mendapati mesej anti-Islam bagi bahagian ini banyak ditonjolkan dari segi suasana negara perang yang menakutkan. Di awal filem American Sniper menunjukkan kesan perang yang teruk di Fallujah, Iraq. Visual pada minit ke 00:31 memaparkan bangunan-bangunan yang kosong yang ditinggalkan oleh penduduk Iraq dengan kesan bedilan bom, bangunan runtuh dan kereta yang tersadai di jalanan.

Sementara itu, minit ke 01:08 pula menunjukkan posisi kamera high angel dari atas bumbung yang menunjukkan kerosakan secara menyeluruh. Visual minit ke 32:59 pula menggambarkan panorama sebuah negara Islam dengan menunjukkan masjid-masjid di tengah kota disusuli juga dengan dua buah helikopter yang sedang berlegar-legar di atas awanan serta kepulan asap bom yang berkepulan di mana-mana. Seterusnya juga minit ke 40:26 menunjukkan keadaan suasana bandar Fallujah yang berasap akibat bedilan bom serta bunyi tembakan.

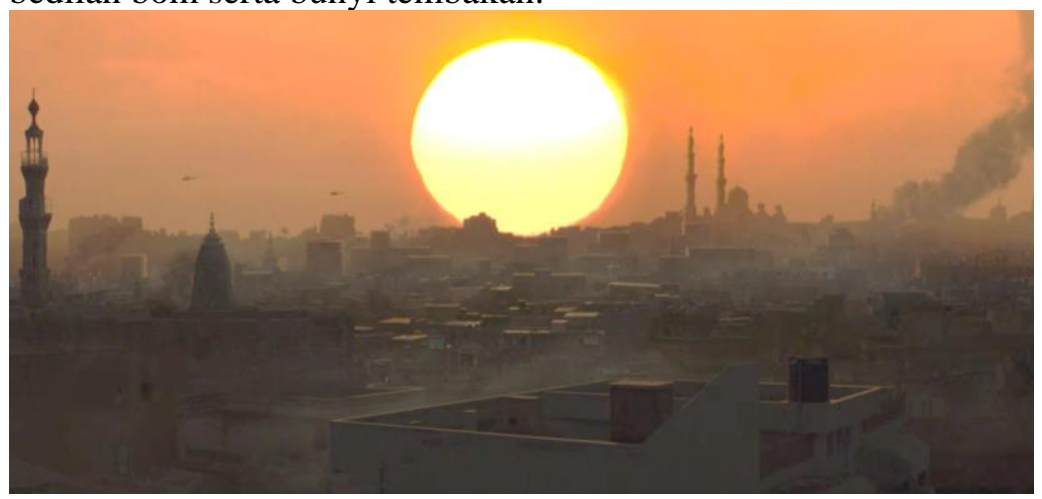

Rajah b i: Panorama Bandar Fallujah dengan kepulan asap di udara. 
Bandar Fallujah merupakan tempat yang dikosongkan ${ }^{42}$ kerana diisytiharkan sebagai zon perang sebagaimana yang diperkatakan oleh Chris Kyle kepada Al-Obeidi pada minit ke 41:25. Namun sebelum berlaku pencerobohan Amerika di Iraq, penduduk di Fallujah menjalani kehidupan normal dan aman.

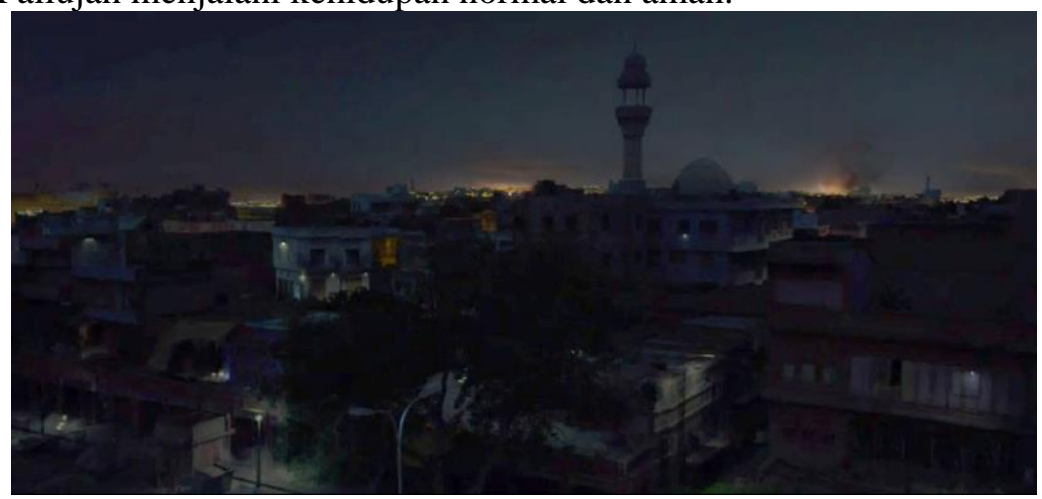

Rajah b ii: Keadaan Bandar Fallujah yang gelap-gelita akibat dikosongkan.

Selain itu juga, visual pada minit ke 01:02:56 menunjukkan letupan-letupan bom di tengah bandar Iraq dari pandangan atas menggunakan teknik kamera berposisi high angle (bird eye view). ${ }^{43}$ Suasana bandar yang gelap gelita dengan panorama masjid dan apartmen-apartmen kosong yang telah dikosongkan amat menakutkan.

Sementara itu, visual pada minit ke 01:25:01 menunjukkan secara jelas bangunan-bangunan yang rosak serta lusuh yang telah ditinggalkan. Pengarah berjaya menunjukkan kepada penonton sebuah pemandangan yang buruk seakan-akan sebuah bandar yang "berhantu". Selain keseluruhan Bandar Baghdad, Bandar Sadr"

${ }^{42}$ Lihat minit 32:06 yang menunjukkan gambaran situasi pada suatu malam yang lengang serta menakutkan dengan penempatan yang dievakuasikan akibat perang.

43 Sudut pengambilan kamera high angle atau dikenali juga sebagai (bird eye view) merupakan posisi kamera lebih tinggi dari objek yang diambil.

44 Bandar Sadr merupakan sebuah bandar penempatan masyarakat Syiah di pinggir kota Baghdad yang sebelumnya di kenali sebagai Bandar Saddam, namun ditukar secara tidak rasmi oleh pemimpin Syiah di Iraq, Ayatullah Mohammad Mohammad Sadeq Al-Sadr sebagai 'Bandar Sadr'. Lihat laman sesawang Summary Results of the Census of Buildings and Installations and 
juga ditonjolkan pada minit ke 1:37:32 menerusi pergerakan kamera dari atas high angle (bird eye view) yang menunjukkan suasana keseluruhan Bandar Sadr yang menakutkan. Gambaran ini mengaitkan sebuah negara Islam yang tidak selamat untuk didiami akibat kehancuran oleh manusia, sedangkan Islam mementingkan keamanan sejagat.

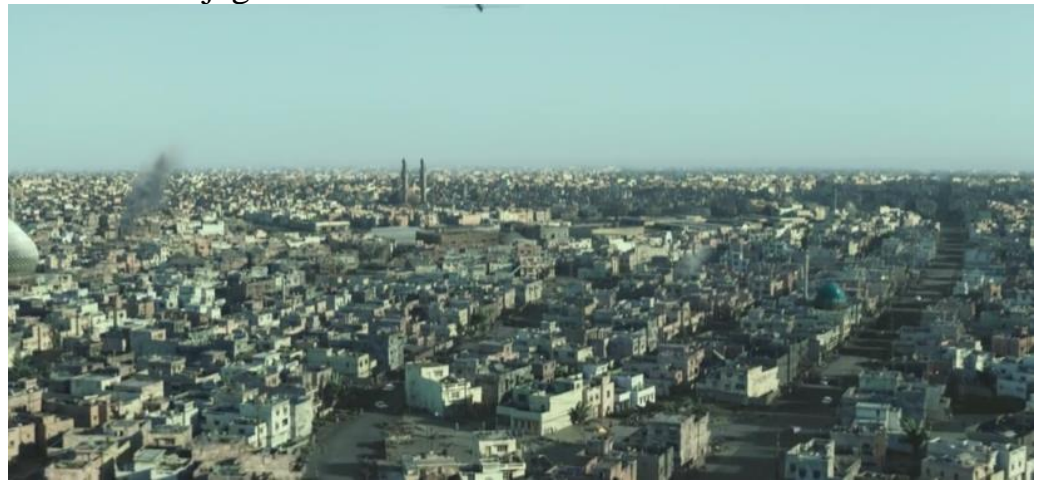

Rajah b iii: Bandar Sadr yang lengang ditayangkan.

Pada babak klimaks pertempuran di antara Chris dan Mustafa yang menyaksikan Mustafa terbunuh, minit ke 01:43:40 ketika Chris melepaskan das tembakan kepada Mustafa yang berjarak 2100 (lebih dari 1 batu), teknik kamera slow-motion ditonjolkan sekaligus memaparkan persekitaran bandar termasuk menaramenara masjid.

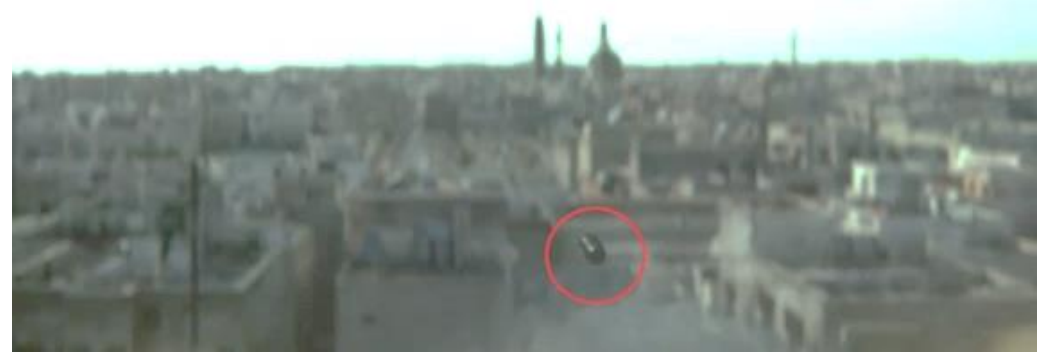

Rajah b iv: Kamera menfokuskan das peluru yang ditembak oleh Chris bersama penonjolan panorama Bandar Fallujah.

Families in 2009, the Iraqi Ministry of Planning, Central Bureau of Statistics Organization, Iraq. www.cosit.gov.iq 
Persekitaran yang menakutkan ditonjolkan pada minit ke 01:48:35 dengan ribut pasir yang besar. Pasukan GRF Viper 34 tersasar melepaskan tembakan dari atas helikopter kerana cuaca ribut pasir yang teruk. Babak cemas sebegini dapat mencipta rasa takut terhadap negara Islam tambahan lagi kebanyakan negara yang sedang bergolak di saat ini ${ }^{45}$ adalah negara-negara Islam. Keadaan bukan sahaja kritikal, malah menakutkan tambahan lagi provokasi yang dicipta oleh barat seperti penempatan tentera Amerika sebagaimana dalam filem ini yang banyak menunjukkan sisi gelap sebuah negara Islam. Kesan perang yang ditonjolkan dalam filem ini berjaya menggambarkan suasana negara Arab yang sentiasa tidak aman dan sering dibom serta meninggalkan rasa takut kepada agama Islam.

Selain daripada babak pemandangan, terdapat beberapa babak yang menimbulkan rasa takut kepada penonton. Antaranya ialah ketika Chris dan anggota NAVY SEAL yang lain baru sahaja mendarat tiba di Iraq ketika Tour One, Marc Lee mengatakan pada minit ke 25:09 tentang ugutan dan ancaman Al-Qaeda terhadap tentera Amerika. ${ }^{46}$

Marc Lee: AQI (Al-Qaeda) have put a price on your heads and extremists from around the globe are flooding the borders to collect into it.

Begitu juga pada Tour Two, saat Chris baru tiba dan memasuki pesawat BlackHawk di Al-Taqaddum AirBase Iraq, Kolonel Jones memegang poster ganjaran Al-Qaeda yang mempunyai gambar senapang riffle dan tato tanda salib. Minit ke 01:11:20 juga menunjukkan di dinding rumah Mustafa ditampal poster ganjaran

45 Di saat pengkaji melakukan penyelidikan ini, suasana di beberapa negara Islam masih bergolak dan berperang seperti di Syria, Yaman, Palestin dan Iraq serta kemelut politik di Arab Saudi dan beberapa negara Timur Tengah yang lain.

46 Di dalam filem ini, Al-Qaeda dikaitkan dengan Islam berdasarkan beberapa analisis sebagai contoh dari aspek sinematografi pada minit ke 01:11:05 yang memaparkan visual suasana di rumah anggota Al-Qaeda bernama Mustafa. Teknik pergerakan kamera menunjukkan sebuah mushaf al-Quran di atas meja, selain penonjolan senjata api. Melalui scene ini, pengarah berjaya menyampaikan mesej Islamofobia melalui kewujudan al-Quran yang diletakkan di rumah pengganas seolah-olah pengganas Islam seperti Mustafa, mengamalkan ajaran al-Quran. Isi kandungan Al-Quran terutamanya ayat-ayat tentang jihad sering disalahtafsir oleh musuh Islam dengan mengaitkan jihad dengan aktiviti keganasan yang menyimpang. 
tersebut. Al-Qaeda dikatakan menawar harga yang tinggi terhadap kepala Chris seperti yang disebut pada minit ke 59:23.

Kolonel Jones: You are the most wanted man in Iraq.

Kapten Martins: There's 180,000 (US Dollar) on your head. Congrats.

Ancaman ini amat menggerunkan dan menakutkan. Pengarah berjaya mencipta scene yang ringkas di dalam pesawat BlackHawk, namun begitu padat dengan mesej propaganda anti-Islam dengan menyemaikan rasa Islamofobia seperti dalam babak ini.

Sementara itu, minit ke 25:59 menunjukkan dialog di antara Winston dan Chris tentang kelicikan Mustafa ketika mereka baru tiba di lokasi panas bagi membuat pengawasan.

Winston: Man, they got this one sniper that's been hitting head shots from 500 yards out.

They call him Mustafa. He's in the Olympics.

Kenyataan sebegini seolah-olah mencuba untuk mencipta rasa takut apabila Winston memaklumkan bahawa terdapat penembak hendap dari kalangan 'muj' ${ }^{47}$ iaitu Mustafa. Tambahan lagi, shot pada minit ke 01:19:36 menunjukkan gambar Mustafa memperoleh medal ketika Sukan Olimpik di Atlanta. Ini menggambarkan Mustafa seorang penembak hendap yang digeruni pihak tentera Amerika.

Selepas selesai taklimat di Kem Tentera Amerika di Fallujah, Chris Kyle merungut tentang tugasan anggota marin yang mendedahkan mereka dengan bahaya, lalu menawarkan dirinya untuk menolong mereka di lapangan. Namun, Mark mengatakan bantahannya pada minit ke 38:40 kerana sangat bahaya, tambahan juga mereka amat memerlukan Chris untuk meneropong dari jauh.

Mark Lee: What's your deal, man? House-to-house is the deadliest job here.

You got some kind of savior complex?

Babak ini pula ketika Chris pulang bercuti di Amerika. Minit ke 1:12:36 menunjukkan reaksi Chris ketika terdengar bunyi gerudi sewaktu berada di bengkel kereta bersama anak lelakinya, Colton. Ekspresi wajah Chris yang fobia kerana bunyi gerudi tersebut menyebabkannya terngiang-ngiang dengan bunyi gerudi di Iraq

47 'Muj' merupakan perkataan singkat kepada 'Mujahidin'. Tentera Amerika yang berada di Iraq menggelarkan 'muj' kepada pemberontak ataupun pengganas. Istilah 'Muj' ini akan dijelaskan dalam analisis name-calling. 
yang digunakan secara kejam oleh 'The Butcher' terhadap mangsanya.

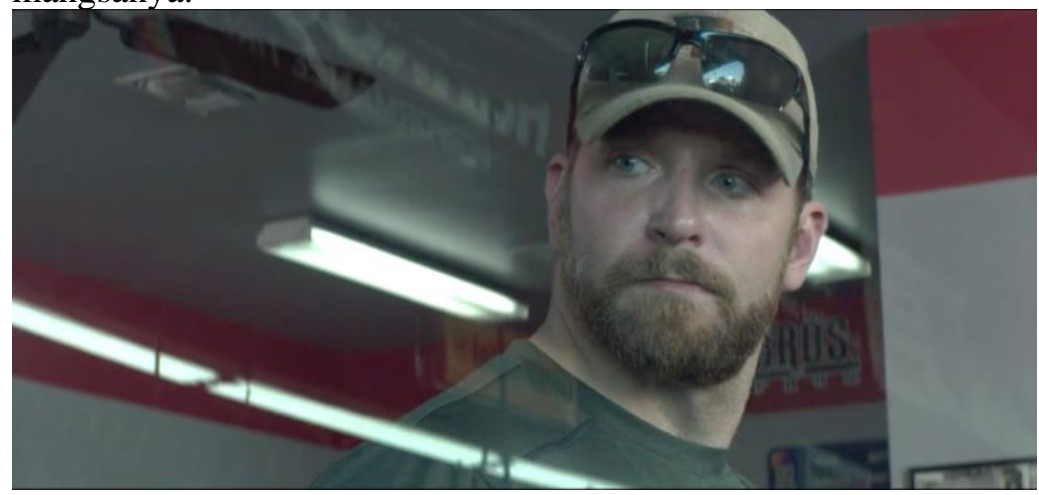

Rajah b vi: Ekspresi wajah Chris ketika terdengar bunyi gerudi di bengkel kereta.

Visual pada minit ke 01:28:41 pula menunjukkan babak ketika Chris baru pulang dari majlis pengebumian Marc Lee. Chris memandang ke arah cermin pandang belakang kerana mendapati terdapat sebuah van putih yang mengekori keretanya terlalu rapat. Fikiran Chris menghantui akan peristiwa hitam di Ramadi, Iraq ketika kenderaan askar AS diekori oleh kumpulan pengganas.

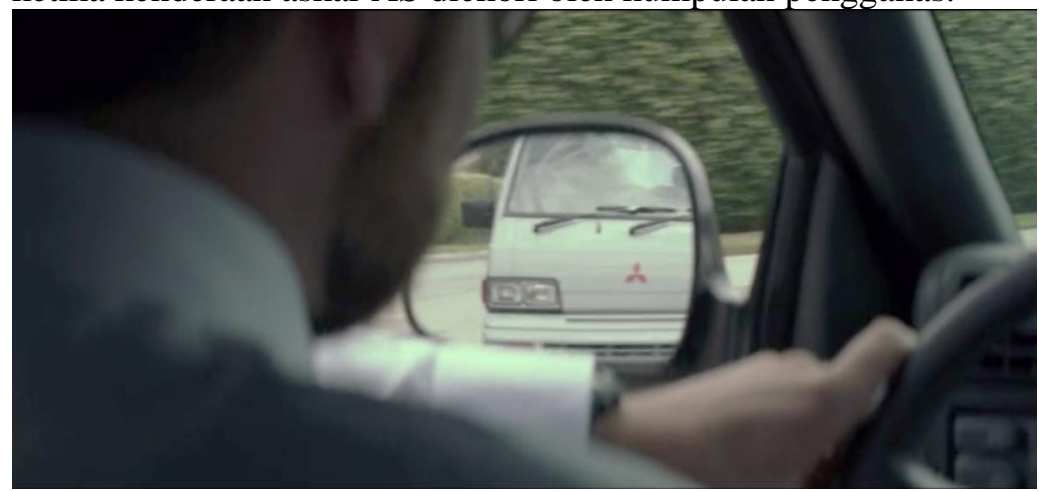

Rajah b vii: Chris memerhatikan van putih di belakang keretanya.

Sementara itu, babak pada minit ke 01:54:06 menunjukkan shot di rumah Chris di Amerika. Chris yang sudah mengambil keputusan untuk pulang ke tanah air terus dihantui dengan momen yang menakutkan di Iraq. Babak ini menunjukkan Chris yang sedang duduk sambil termenung bersendirian berhadapan televisyen di ruang tamu rumahnya, namun bunyi tembakan 
bertalu-talu, letupan bom, helikopter askar serta jeritan anak Obeidi yang digerudi anggota badannya tetap berlegar-legar di fikirannya.

Babak pada minit ke 01:55:43 menunjukkan suasana majlis hari jadi anak mereka Colton. Tiba-tiba seekor anjing bertindak ganas ke atas rakan sebaya Colton. Lantas Chris berlari mendapatkan anjing tersebut dan hampir memukul anjing tersebut menggunakan tali pinggangnya namun Taya sempat menjerit dengan kuat agar Chris menyedari tindakannya tersebut. Chris bertindak di luar kawalan di atas kesan fobianya terhadap anjing yang menyerangnya dalam sebuah pertempuran sengit di Fallujah, Iraq.

Pada hujung babak terakhir filem menunjukkan perbualan di antara Chris dan seorang doktor NAVY. Doktor tersebut menyatakan tentang rasa kekesalan Chris terhadap aksi-aksi tembakan yang pernah dilakukannya sepanjang berkhidmat di Iraq, lalu Chris menjawab pada minit ke 01:56:55;

Chris: They were trying to kill our soldiers, and i'm willing to meet my creator and answer for every shot that $i$ took.

Kenyataan Chris ini menggambarkan kekejaman yang dilakukan oleh umat Islam di Iraq, memandangkan Chris merujuk kepada 'They' tanpa menspesifikasikan golongan pengganas ataupun pemberontak.

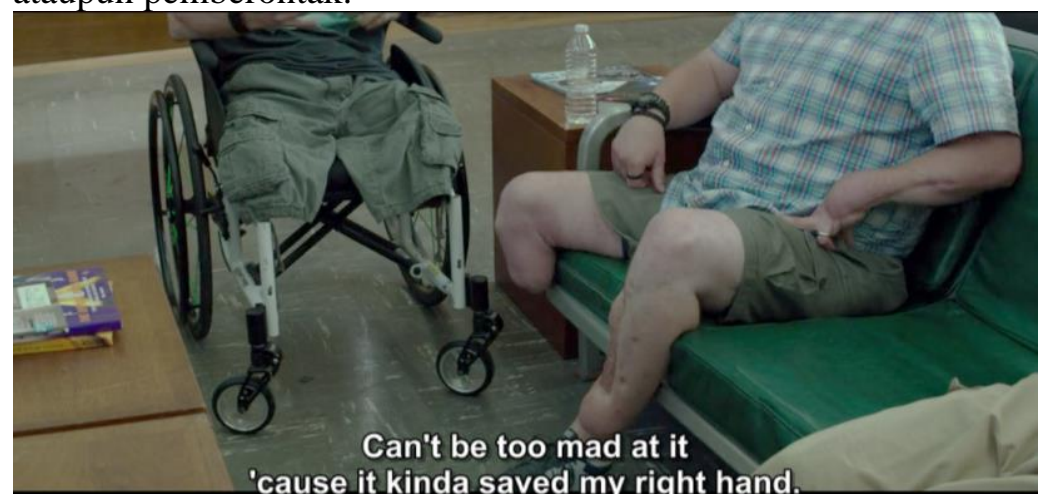

Rajah b viii: Bryan dan Wynn menceritakan pengalaman tragik di Iraq sehingga mengakibatkan mereka kehilangan kaki mereka.

Pada kesinambungan babak tersebut, minit ke 1:57:46 menunjukkan doktor tersebut mengajak Chris untuk bertemu dengan askar veteran AS yang mengalami kecacatan seumur hidup dan sedang menerima rawatan di Hospital Veteran Tentera, San 
Diego. Chris beramah mesra bersama Bryan dan Wynn, anggota veteran askar yang masih muda. Bryan, salah seorang veteran askar yang kudung kaki dan tangannya menceritakan pengalaman kisah benar di saat bom meletup sehingga mengakibatkan kedua-dua belah kaki dan tangan kirinya kudung. Aspek sinematografi dalam babak ini amat berkesan apabila kamera zoom track-in yang mengfokuskan ke arah kaki kudung kedua-dua askar tersebut ditonjolkan kepada penonton. Shot ke atas anggota badan yang cacat sebegini dapat mencipta rasa takut kepada penonton.

Filem 13 Hours: The Secret Soldiers of Benghazi pula memulakan epilog yang mengatakan bahawa Tripoli dan Benghazi merupakan antara tempat merbahaya di dunia. Plot cerita bermula dengan menunjukkan visual asal pergolakan negara Libya dengan pembunuhan Muammar Gaddafi, serangan udara oleh AS, Perancis dan British. Di akhiri dengan jutaan rakyat Libya berkumpul meraikan kemenangan. Selain itu juga visual menunjukkan paparan asli tembak menembak dalam pertempuran di antara askar militan dan askar kerajaan. Penerangan epilog yang mengklasifikasikan Tripoli dan Benghazi sebagai tempat paling bahaya di dunia dikatakan oleh kementerian AS sebagai ancaman yang 'kritikal'. Aksi keganasan diluar batas kemanusiaan ditonjolkan dengan paparan struktur bangunan yang rosak dan berlubang akibat dibedil oleh bom, kereta, kereta kebal, manakala kapal terbang hancur, tembakan peluru bertalu-talu dan ledakan peluru berpandu ke arah 'target' sehinggakan penutupan semua kedutaan (kecuali AS). Fenomena sebegini cukup untuk menggambarkan rasa ketakutan dan tidak selamat utuk menjejak ke negara Libya. Meskipun hal ini memang benar-benar terjadi namun filem ini sememangnya berjaya menyemai rasa fobia terhadap Islam melalui kesan kehancuran yang ditonjolkan. ${ }^{48}$

Begitu juga di dalam babak-babak seterusnya yang mempamerkan pemandangan yang menakutkan seperti pada minit ke 2:52 yang menunjukkan kapal terbang yang terbelah dua dan kereta kebal yang musnah seperti di bom. Shot ini diambil dari

48 Berikut merupakan epilog di pembukaan filem pada minit ke 00:37 dan 01:57 yang berbunyi; "2012= the united state had 294 diplomatic outposts worldwide. 12 were in places so dangerous the state department deemed them threat level "critical". two were in libya: tripoli and benghazi.violent turf wars broke out. Benghazi became one of the most dangeorus places on earth." 
pandangan udara iaitu kamera berposisi high angle (bird eye view). Persembahan babak di awal filem sebegini mampu mencipta rasa takut selain daripada penyebaran propaganda pengarah filem dalam mempengaruhi perasaan cemas dalam mind-set penonton.

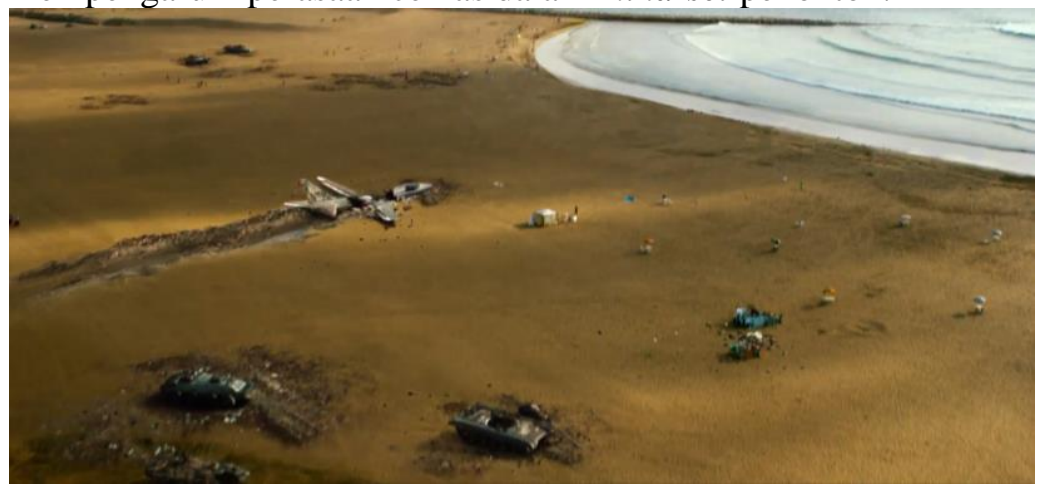

Rajah b ix: Penonton dipersembahkan dengan

gambaran kesan bedilan bom di awal filem 13 Hours.

Selain daripada itu juga, pergerakan kamera secara close-up pada minit ke 3:40 memfokuskan kepada sebuah bangkai pesawat AFRICAN ARROW yang dibom dan ditinggalkan di Lapangan Terbang Benina, Benghazi. Keadaan airport ini sangat teruk dan daif dengan kesan lubang dari tembakan dan bom di hampir seluruh bangunan airport. Manakala minit ke 5:50 pula menunjukkan bangunan buruk yang kelihatan seperti dibakar dan dibom tatkala Jack baru sahaja mendarat dan memasuki kawasan pekan Benghazi.

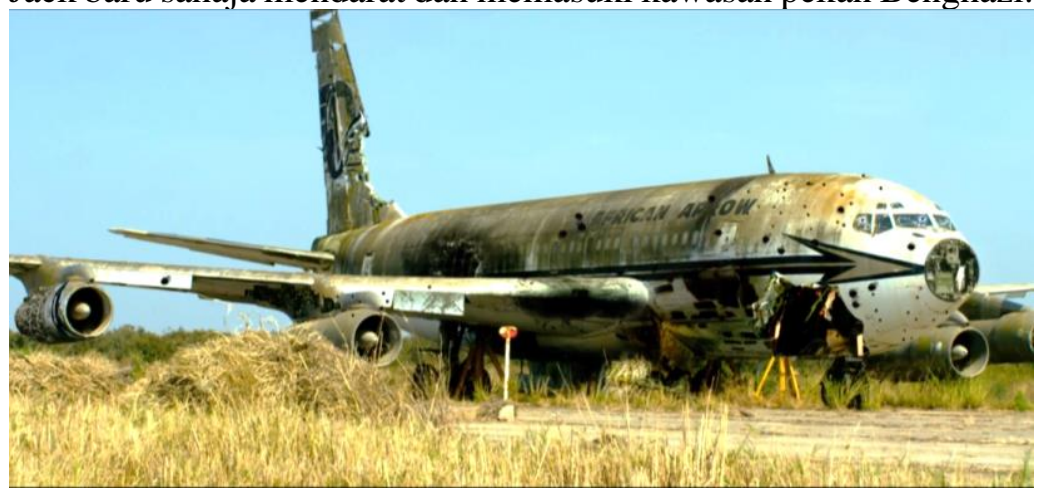

Rajah b x: Antara pemandangan awal Libya ketika Jack baru mendarat di Lapangan Terbang Benina.

Sementara itu, minit ke 13:03 menunjukkan dialog antara Jack dengan Tig yang menggelarkan tempat penyembelihan binatang 
yang busuk di kawasan markas CIA sebagai Zombieland sambil kamera shot secara slow motion terhadap orang-orang tua berkopiah putih yang sedang meminum teh manakala kanak-kanak juga memakai kopiah putih dan mengikat tudung sambil berlari keriangan. Sebagaimana yang kita tahu, zombi bermaksud mayat hidup dan memakan manusia. Penggelaran buruk seperti ini mencipta rasa takut terhadap Tanah Arab ini. ${ }^{49}$

Selain itu, Duta AS di Libya, Chris Stevens dalam taklimatnya di Markas CIA telah menyenaraikan negara-negara Islam (Mesir dan Syria) yang sedang bergolak. Kenyataan pada minit ke 29:56 tersebut seolah-olah memberi gambaran tentang situasi yang tidak selamat dan merbahaya di beberapa negara Islam seperti yang berlaku di Mesir dan Syria. ${ }^{50}$

Sementara itu, jika penonton melihat minit ke 34:34 sudah cukup mencipta rasa fobia apabila teknik sinematografi yang dipraktikkan dalam shot ini mengundang rasa ketakutan terhadap Islam. Visual ini menunjukkan shot persekitaran kubur-kubur orang Islam dengan pergerakan kamera pan-shot ke kanan (pan right) di samping gerakan kamera track-in yang memfokuskan pada pembesar suara serta disusuli juga dengan paparan serangan 11/9 di televisyen. Tanpa menggunakan sebarang dialog, shot ini menakutkan kerana bunyi siren yang berselingan dengan azan itu mendebarkan.

\section{Kebencian Melampau}

Di dalam filem American Sniper, terdapat banyak babak yang menunjukkan kebencian terhadap Islam berbanding filem 13 Hours yang sedikit sahaja. Antaranya pada minit ke 22:47, babak yang sangat pendek iaitu hanya 4 saat sahaja ditonjolkan aksi Chris menembak ketika latihan dengan wajahnya yang penuh dendam selepas mengetahui tentang World Trade Centre (WTC) yang diserang pengganas. Selain itu, ketika Marc Lee bertanyakan kepada Chris tentang jumlah musuh yang berjaya ditembak olehnya, Chris menjawab sambil wajahnya mempamerkan geram

49 Selain daripada mencipta Islamofobia dari penggelaran 'Zombieland' ini, penggelaran ini juga dikategorikan sebagai teknik propaganda name-calling.

50 Dialog ucapan Duta berbunyi sebegini; "So between what we see happening in Egypt with Morsi and the current destabilization of Syria, yes, it's easy to imagine any number of scenarios playing out here". 
dan terus berlalu pergi meninggalkan Marc. Babak ini ditonjolkan pada minit 33:36.

Chris: Yeah, but they got one of us

Selain itu juga, terdapat beberapa babak minit ke 49:39 mempamerkan sikap benci Chris terhadap Islam apabila Chris melepaskan tembakan dengan mempamerkan ekspresi wajahnya yang sedang berdendam dengan musuhnya yang beragama Islam iaitu Mustafa. Sementara itu, babak pada minit ke 50:38 menunjukkan aksi Chris membuat senaman dengan mengangkat berat dengan wajah yang penuh dendam kesumat selepas tidak berjaya membunuh Mustafa. Mustafa telah menembak mati beberapa askar Amerika. Babak ini hanya mempamerkan wajah Chris yang geram berserta sound track yang mendebarkan, tanpa menggunakan sebarang dialog.

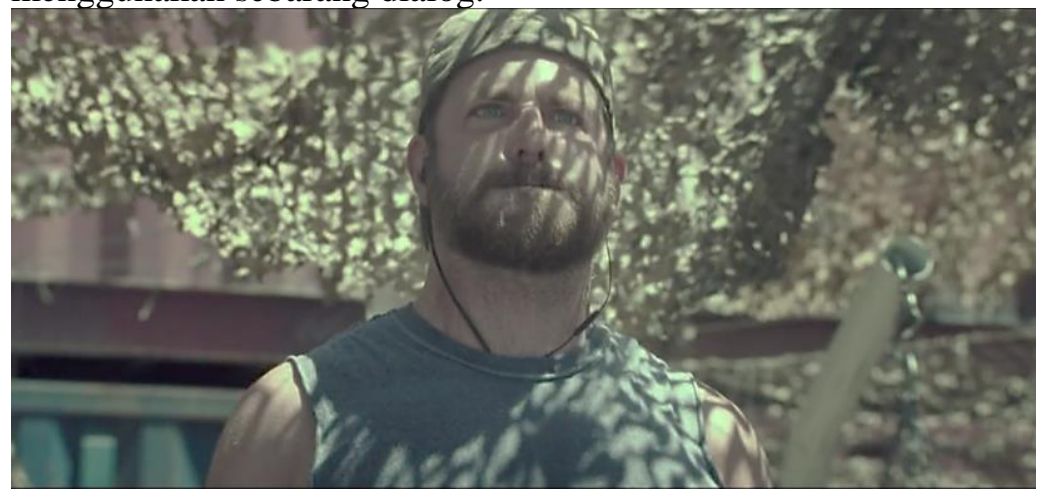

Rajah c i: Reaksi wajah dendam Chris terhadap musuh Islam.

Seusai taklimat di dalam khemah operasi, Marc Lee menyuarakan tentang apa yang sedang mereka lakukan di Iraq. Chris cuba meyakinkan kepada Marc bahawa terdapat kejahatan di bumi Iraq dan mereka sedang berjuang melawannya. Ujar Chris juga, kejahatan itu boleh sampai hingga ke San Diego dan New York (01:01:06). Lalu Marc membalas dengan mengatakan "Mari bunuh mereka". Ajakan membunuh sebegini menggambarkan kebencian terhadap kumpulan pengganas Muslim yang telah melakukan serangan seperti menara WTC.

Minit ke 01:19:18 menunjukkan Chris bersama Biggles serta kumpulan mereka di dalam trak menuju ke lokasi musuh. Biggles menyarankan agar Chris berusaha untuk menembak Mustafa jika berpeluang berbuat demikian. Babak yang lain pula menunjukkan 
Chris yang menziarahi Biggles yang terlantar di hospital. Chris dengan nada yang sedih mengatakan bahawa dia akan kembali berjuang di Iraq. Biggles dengan nada lemah, tidak bersetuju untuk Chris kembali ke sana.

Chris: Oh, we have to do that. You're my brother.

And they're gonna fucking pay for what they did to you.

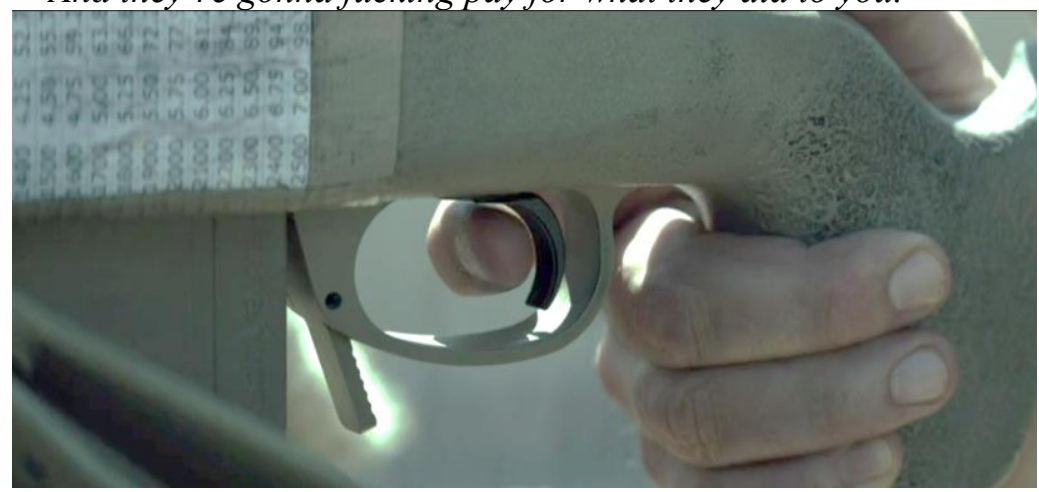

Rajah c ii: Kamera zoom ketika Chris ingin menembak Mustafa.

Dialog di atas bermaksud dendam kesumat Chris ke atas musuh mereka yang telah menembak sahabat baiknya, Biggles. Kesinambungannya, minit ke 01:43:32 menunjukkan aksi Chris yang mendebarkan ketika melepaskan tembakan tepat terhadap Mustafa. Kamera zoom terhadap Chris yang sedang memetik pemicu tembakan. Chris bermonolog luaran dengan mengatakan "Lakukan (tembak) demi Biggles". Kenyataan ini menunjukkan seolah-olah Chris ingin membalas dendam terhadap musuh. Perasaan dendam atau 'revenge' yang tersirat di hati Chris sepertimana telah termaktub pada artikel "How 'American Sniper' Chris Kyle's Truthfulness is in Question Once Again” dalam akhbar dalam talian Amerika, Washington Post. Artikel ini mengatakan bahawa filem ini banyak menyimpang daripada peristiwa sebenar semata-mata untuk mencipta kesan dramatik terutamanya watak penjahat, Mustafa yang tidak pernah disebut dalam buku aubiografi American Sniper serta babak Chris ingin membalas dendam atas pembunuhan Biggles oleh pengganas Muslim. ${ }^{51}$ Realitinya Biggles

51 Dan Lamothe, "How 'American Sniper' Chris Kyle's Truthfulness is in Question Once Again”, dicapai 15 April 2019, laman sesawang Washington Post, https://www.washingtonpost.com/news/checkpoint/wp/2016/05/25/how- 
meninggal dunia beberapa tahun selepas kembalinya dari Iraq, bukan sejurus selepas ditembak oleh Mustafa seperti yang ditonjolkan dalam filem. Jadi terbukti bahawa dendam yang dicipta oleh pengarah sebagai sebuah mesej anti-Islam dalam menyelewengkan fakta dan penciptaan kesan dramatik dalam plot filem.

Sementara itu, Kolonel Gronski menyeru kesemua askar untuk menangkap Abu Musab al-Zarqawi secara hidup-hidup mahupun mati. Seruan itu dilafazkan dengan penuh kebencian pada minit ke 38:17 kerana Zarqawi dikatakan sebagai pimpinan Al-Qaeda paling terkenal dalam pemberontakan terhadap tentera AS di Iraq.

Sementara itu babak pada minit ke 41:14 menunjukkan aksi kasar Chris dan sekumpulan askar Marin yang menggempur rumah al-Obeidi. Seorang askar marin menumbuk muka al-Obeidi manakala Chris mengacukan senapang ke arah anak lelaki al-Obeidi yang bisu. Aksi ini menunjukkan sikap kebencian melampau terhadap Muslim. Sedangkan itu rumah mereka sendiri namun tidak dipedulikan oleh Chris dan askar-askar marin sebagaimana dialog pada minit 41:20.

Sheikh al-Obeidi: I am Sheikh al-Obeidi.

Chris Kyle: Sheik alla-who?! Who the fuck are you?!

Sheikh al-obeidi: This is my home! I stay!

Chris Kyle: I don't give a fuck it's your home!

Ketika Chris baru mendarat di Iraq bagi Tour 2 (minit ke 58:20), Chris terserempak dengan adiknya Jeff yang ingin berlepas pulang ke Amerika. Jeff mengatakan bangga dengan abangnya. Sebelum meninggalkan abangnya, Jeff menzahirkan kebencian dengan kata-kata; 'Fuck this place' sebanyak dua kali. Kata-kata ini jelas menunjukkan kebencian Jeff yang tidak suka dengan negara peperangan seperti Iraq. Selain itu juga, Jeff mengatakan bahawa dia sudah penat dan ingin pulang ke tanah air mereka.

Terdapat juga beberapa babak yang menampilkan dialog ketika taklimat samada di dalam pesawat mahupun di dalam khemah operasi. Arahan yang diberikan berdasarkan dialog yang diucapkan mempunyai unsur kebencian terhadap Islam. Sebagai contoh, pada minit ke 59:43 menunjukkan Kolonel John yang

american-sniper-chris-kyles-truthfulness-is-in-question-once-again/?noredirect $=$ on\&utm_term $=.26179 \mathrm{ad} 24565$. 
memandang tajam terhadap Chris dengan nada yang keras dengan mengatakan;

Kolonel John: I want you to put the fear of God into these savages and find his ass.

Selain Kolonel John, Leftenan Martin juga memberi taklimat tentang misi seterusnya pada minit ke 1:36:44. Kenyataan Leftenan ini jelas mempunyai unsur kebencian terhadap musuh Amerika kerana yang penting katanya, Mustafa perlu mati dalam apa jua hal sekalipun.

Leftenan Martin: He can be whoever the fuck you need him to be.

We just need him dead.

We need to shut this shooter down.

Di dalam filem 13 Hours: The Secret Soldiers of Benghazi, Islamofobia dari sudut pandang 'kebencian yang melampau' terhadap Islam dan Muslim ditunjukkan di dalam beberapa lakon layar sahaja kerana elemen Islamofobia yang lain seperti sikap prejudis, stereotaip, diskriminasi dan ketakutan yang tidak rasional sudah banyak ditonjolkan di dalam filem ini. Propagandis bijak mencipta propaganda iaitu mesej anti-Islam yang tersembunyi itu disampaikan dengan banyak di dalam filem, manakala mesej secara terang-terangan seperti kebencian melampau disampaikan dalam kadar yang sikit. Hal ini dapat dibuktikan pada minit ke 1:55:32 apabila Tanto secara terang-terangan mengeluh dan seolah-olah tidak suka mendengar azan ketika azan berkumandang.

Tanto: All right. Weird shit's (Azan) starting to happen now.

I've had just about enough of this 2012 bullshit.

Can we get the fuck out of here now?

Manakala pada minit ke 1:55:06 pula, Tanto seolah-olah meluahkan rasa benci terhadap pengganas Muslim.

Tanto: I want to shoot this guy, Rone.

Rone, i'm gonna shoot him in the face.

Dialog di atas menunjukkan Tanto menonjolkan rasa geram untuk tembak di wajah musuh. Babak ini menunjukkan sekumpulan pengganas Muslim yang datang untuk memerhatikan sasaran iaitu rakyat Amerika. 


\section{Penutup}

Menerusi kajian ini dapat dilihat bahawa tiga elemen utama di dalam mesej anti-islam Islamofobia iaitu sikap prejudis, stereotaip dan diskriminasi, ketakutan tidak berasas dan yang terakhir, kebencian melampau wujud di dalam kedua-dua filem ini. Menerusi penjelasan analisis sebelum ini, dapat dirumuskan bahawa elemen prejudis, stereotaip dan diskriminasi terhadap Islam di dalam filem 13 Hours lebih banyak ditonjolkan berbanding filem American Sniper yang menampilkan empat babak sahaja. Hal ini kerana pengkaji mendapati pengarah 13 Hours lebih memfokuskan terhadap pemandangan Libya sebagai sebuah negara yang sedang bergolak kerana dari awal filem pengarah telah menampilkan cebisan prolog yang tertulis 'Libya merupakan negara yang paling berbahaya di dunia'.

Manakala elemen ketakutan tidak berasas terhadap Islam ditonjolkan lebih kurang 24 babak di dalam filem American Sniper berbanding filem 13 Hours yang hanya lapan babak sahaja. Dalam filem American Sniper, elemen ketakutan tidak rasional ini banyak menonjolkan suasana Iraq sebagai sebuah negara perang yang berbahaya. Namun, hakikat sebenar yang berlaku di negara Iraq bukanlah sebagaimana yang digambarkan menerusi filem American Sniper.

Hakikatnya, perang Iraq dimulakan oleh kerajaan Amerika sendiri di bawah pimpinan Presiden Bush dan sekutu kuatnya, Britain di bawah Presiden Tony Blair melancarkan pencerobohan ke atas Iraq pada tahun 2003 atau dikenali sebagai '2003 Invasion of Iraq' ${ }^{52}$ Serangan besar-besaran dilakukan ke atas Iraq kerana propaganda fitnah A.S bahawa Iraq sedang membangunkan teknologi dan menyimpan senjata nuklear jenis Pemusnahan Massal (Weapons of Mass Destruction-WMD) yang mengancam keselamatan mereka dan juga sekutu-sekutu serantau serta seperikatan mereka, sehinggakan Saddam Hussein dilabel sebagai "musuh dunia nombor satu.". ${ }^{53}$ Namun, dakwaan yang menjadi

52 Frontline PBS, "Operation Iraqi Freedom", laman sesawang Public Broadcasting Service (PBS), dicapai 15 April 2019, www.pbs.org/wgbh/pages /frontline/shows/invasion/cron/.

53 Senate, "New Information on Iraq's Possession of Weapons of Mass Destruction", laman sesawang Federation of American Scientists (FAS), dicapai 15 April 2019, https://fas.org/irp/congress/2004_cr/s012804b.html. 
alasan untuk "Perang Melawan Terrorisme" di Iraq tersebut tidak terbukti sehingga kini. ${ }^{54}$ Malah pada tahun 2004, Setiausaha Agung Pertubuhan Bangsa-Bangsa Bersatu (PBB), Kofi Annan telah menegaskan bahawa pencerobohan itu adalah tidak sah mengikut undang-undang antarabangsa serta menyalahi piagam Pertubuhan Bangsa-Bangsa Bersatu (PBB). ${ }^{55}$

Sementara itu, elemen kebencian terhadap Islam ditonjolkan hanya dua babak sahaja menerusi filem 13 Hours, manakala filem American Sniper terdapat 13 babak yang dikesan mempunyai unsur kebencian tersebut.

Begitu juga sikap prejudis, stereotaip dan diskriminasi terhadap Islam dan penganutnya yang dapat dilihat dalam beberapa babak samada dari aspek lakon layar filem mahupun aspek sinematografi. Aspek lakon layar lebih banyak ditemui di dalam kedua-dua filem berdasarkan dialog dan teks yang diucapkan oleh watak yang mempunyai unsur prejudis dan stretrotaip berbanding aspek sinematografi yang hanya sedikit seperti shot kanak-kanak yang melakukan aktiviti keganasan.

Pada perspektif Islam, gejala Islamofobia yang wujud pada zaman ini bertepatan dengan ayat al-Quran sebagaimana firman Allah SWT:

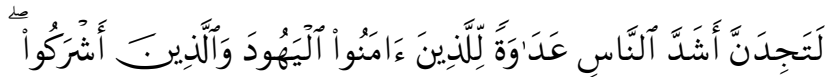

Al-Mā'idah 5: 82

Terjemahan: Demi sesungguhnya engkau (wahai Muhammad) akan dapati manusia yang keras sekali permusuhannya kepada orang-orang yang beriman ialah orang-orang Yahudi dan orang-orang musyrik.

Ironinya, tanpa melihat dari kaca mata terminologi, Islamofobia telahpun berlaku sejak zaman penentangan Abu Jahal dan pengikutnya terhadap Islam dan Nabi Muhammad SAW di

54 Marniati, "Sikap Saddam Husein Ini Alasan Mengapa AS Serang Irak pada 2003", laman sesawang Republika, dicapai 15 April 2019, https://www .republika.co.id/berita/internasional/timur-tengah/16/05/29/o7xjg0320-sikapsaddam-husein-ini-alasan-mengapa-as-serang-irak-pada-2003.

55 David Milliken dan Kylie MacLellan, "Former UK deputy PM Prescott Says Now Considers Iraq Invasion Illegal", laman sesawang Reuters, dicapai 27 April 2019, www.reuters.com/article/us-britain-iraq-prescott/former-uk-deputy -pm-prescott-says-now-considers-iraq-invasion-illegal-idUSKCNOZPOWY. 
tanah arab khususnya di Mekah. ${ }^{56}$ Pelbagai serangan dan tentangan yang dilakukan oleh Abu Jahal dan konco-konconya terhadap Nabi SAW. Beliau merupakan penentang utama Rasulullah SAW dalam menyebarkan dakwah Islamiyyah. Abu Jahal sanggup mati kerana kebenciannya yang tinggi terhadap Nabi Muhammad SAW. ${ }^{57}$ Apabila kebencian mereka meningkat menjadi perang besar, Allah SWT mendedahkan ayat berikut bagi menghadapi mereka. ${ }^{58}$

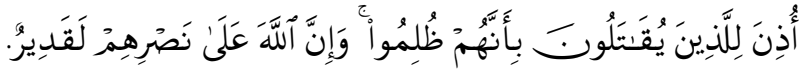

Al-Hajj 22:39

Terjemahan: Telah diizinkan (berperang) bagi orang-orang yang diperangi kerana sesungguhnya mereka telah dianiaya. Dan sesungguhnya Allah, benar-benar Maha Kuasa menolong mereka itu.

Natijahnya, pengkaji melihat bahawa penerbit filem selaku propagandis berjaya menyebarkan gejala Islamofobia menerusi kedua-dua filem Hollywood ini dari aspek sinematografi dan aspek lakon layar. Justeru itu, umat Islam perlu berusaha mengekang sentimen Islamofobia ini mahupun membanteras melalui media seperti filem ataupun media sosial. Langkah yang konsisten dan serius perlu diambil agar kesucian Islam terus terpelihara.

\section{Rujukan}

"13 Hour: The Secret Soldier of Benghazi." Laman sesawang Movies Wikia. Dicapai 27 Mac 2019, http://movies.wikia.com /wiki/13_Hours:_The_Secret_Soldiers_of_Benghazi.

"13 Hours (2016)." Laman sesawang IMDB, dicapai 22 Mac 2019, https://www.imdb.com/title/tt4172430/.

"American Sniper (2014)." Laman sesawang $I M D B$, dicapai 3 Januari 2019, http://www.imdb.com/title/tt2179136/awards.

"American Sniper (2014): Company Credit." Dicapai 14 Januari 2019, http://www.imdb.com/title/tt2179136/companycredits?ref _=ttpl_ql_dt_5

56 Haji Husseiny Zambery, Fobia Yahudi dan Barat Terhadap Islam (Batu Caves: Al-Hidayah Publication, 2010), 103.

57 Abdul Latip Talib, Ikramah Penentang Jadi Pembela (Batu Caves: PTS Publication, 2010), 150.

58 Zakir Husain, "Islam and the Modern Age," Journal Islam and the Modern Age, volume xxxix, no. 3 (Ogos 2008), 80. 
“American Sniper.” Dicapai 3 Januari 2016, http://www.allmovie .com/movie/american-sniper-v581791/cast-crew.

“American Sniper.” Dikemaskini 2 Januari 2016, dicapai 14 Januari 2019, http://www.boxofficemojo.com/movies/?page=main\&id= americansniper.htm.

"American Sniper: The Autobiography of the Most Lethal Sniper in U.S. Military History" karya Mendiang Chris Kyle di pautan http://elibrary.bsu.az/books_163/N_20.pdf.

"Islamofobia Serlah Sikap Perkauman Rakyat Amerika," Berita Harian, 15 Disember 2015, 30.

A Beydoun, Khaled. "How Muslim Ban Incites Vigilante Islamophobic Violence," laman sesawang Al-Jazeera.com, dicapai 12 Mac 2019 http://www.aljazeera.com/indepth/opinion /2017/03/muslim-ban-incites-vigilante-islamophobic-violence170307065614706.html.

Abdul Aziz. "Menangkal Islamofobia melalui Re-InterpretasiAlQuran." Jurnal Pemikiran Islam dan Filsafat (Al-A 'raf), Vol 13, No 1 (2016), 71.

Abdul Latip Talib. Ikramah Penentang Jadi Pembela. Batu Caves: PTS Publication, 2010.

Ackerman, Spencer. "US To Continue 'Signature Strikes' on People Suspected of Terrorist Links", laman sesawang The Guardian. Dicapai 10 Disember 2019, https://www.theguardian .com/us-news/2016/jul/01/obama-continue-signature-strikes-dro nes-civilian-deaths.

Bazian, Hatem. "National Entry-Exit Registration System: Arabs Muslims and Southeast Asians and Post-9/11 "Security Measures", Islamophobia Studies Journal," Volume 2-Issue 1, (Spring 2014), 83.

Block, Alex Ben. "The Making of 'American Sniper': How an Unlikely Friendship Kickstarted the Clint Eastwood Film," laman sesawang HOLLYWOOD REPORTER. Dicapai 22 Mac 2019, https://www.hollywoodreporter.com/news/making-americ an-sniper-how-an-760963.

Esposito John L. dan Mogahed, Dalia Who Speaks For Islam?: What a Billion Muslims Really Think. New York: Gallup Press, 2007). 
Frontline PBS, “Operation Iraqi Freedom", laman sesawang Public Broadcasting Service (PBS). Dicapai 15 April 2019, www.pbs.org/wgbh/pages/frontline/shows/invasion/cron/.

Gubo, Darara Timotewos. Blasphemy and Defamation of Religions in a Polarized World: How Religious Fundamentalism Is Challenging Fundamental Human Rights. London: Lexington Books, 2015.

Haji Husseiny Zambery. Fobia Yahudi dan Barat Terhadap Islam. Batu Caves: Al-Hidayah Publication, 2010.

Haji Norarfan Haji Zainal. "Perpaduan Ummah: Pengalaman Negara Brunei Darussalam," dalam Perpaduan Ummah Merentasi Ideologi, ed. Asyraf Isyraqi Jamil. Petaling Jaya: Rabitah Antarabangsa Alumni al-Azhar Malaysia, 2015.

Hinton, Carla. "Q\&A with Islamic Studies Scholar John L. Esposito", laman sesawang Oklahoman.com. Dicapai 10 Disember 2019, https://oklahoman.com/article/3954360/qawith-islamic-studies-scholar-john-l-esposito?.

Ihsanoglu, Ekmeleddin. "1st OIC Observatory Report on Islamophobia." Laporan, 35th Session of the Council of Foreign Ministers (May 2007- March 2008.

Laman sesawang Summary Results of the Census of Buildings and Installations and Families in 2009, the Iraqi Ministry of Planning, Central Bureau of Statistics Organization, Iraq. www.cosit.gov.iq Lamothe, Dan. "How 'American Sniper' Chris Kyle's Truthfulness is in Question Once Again." Dicapai 15 April 2019, laman sesawang Washington Post, https://www.washingtonpost.com /news/checkpoint/wp/2016/05/25/how-american-sniper-chris-ky les-truthfulness-is-in-question-once-again/?noredirect=on\&utm _term $=.26179 \mathrm{ad} 24565$.

Lathifah Ibrahim Khadhar. Ketika Barat Memfitnah Islam, terj. Abdul Hayyie Alkattani. Jakarta: Gema Insani Press, 2005.

Levy Arnaldo dan Bohari Muslim. Ragam Pesona Batu Nusantara. Jakarta: Wahyumedia, 2015.

Marniati. "Sikap Saddam Husein Ini Alasan Mengapa AS Serang Irak pada 2003", laman sesawang Republika. Dicapai 15 April 2019, https://www.republika.co.id/berita/internasional/timur-ten gah/16/05/29/o7xjg0320-sikap-saddam-husein-ini-alasan-menga pa-as-serang-irak-pada-2003. 
Meer, Nasar dan Modood, Tariq. "Refutations of Racism in the 'Muslim Question' dalam Anti-Muslim Prejudice in the West, Past and Present," Journal Patterns of Prejudice, Volume 43 (2009), 340.

Milliken, David dan MacLellan, Kylie. "Former UK deputy PM Prescott Says Now Considers Iraq Invasion Illegal", laman sesawang Reuters. Dicapai 27 April 2019, www.reuters.com /article/us-britain-iraq-prescott/former-uk-deputy-pm-prescott-s ays-now-considers-iraq-invasion-illegal-idUSKCNOZP0WY.

Mohd Mizan Aslam. Bahaya Fahaman Ekstremis Sayap Kanan (Kolumnis Awani), laman sesawang Astro Awani, dikemaskini 19 Mac 2019, dicapai 27 April 2019, http://www.astroawani.com /berita-malaysia/bahaya-fahaman-ekstremis-sayap-kanan-201602.

Mohd. Farid bin Mohd Shahran. "Islamofobia: Mengubah Ketakutan Kepada Penghormatan." Laman sesawang IKIM, dicapai 10 Disember 2019, http://www.ikim.gov.my/new-wp/ind ex.php/2019/12/06/islamofobia-mengubah-ketakutan-kepada-pe nghormatan-2/.

Nadal, Kevin L.et al. "Subtle and Overt Forms of Islamophobia: Microaggressions toward Muslim Americans", Journal of Muslim Mental Health, Vol. 6, Issue 2, (2012), 16.

OIC Observatory Report on Islamophobia, Mei 2007 - Mac 2008. http://ww1.oic-oci.org/uploads/file/Islamphobia/islamphobia_re p_may_07_08.pdf

Rana, Junaid. "The Story of Islamophobia," Souls: A Critical Journal of Black Politics, Culture, and Society, vol. 9, no.2, (2007), 148-62, (149).

Saylor, "The U.S. Islamophobia Network: Its Funding and Impact," Islamophobia Studies Journal, Volume 2-Issue 1, (Spring 2014), 100.

Senate. "New Information on Iraq's Possession of Weapons of Mass Destruction", laman sesawang Federation of American Scientists (FAS), dicapai 15 April 2019, https://fas.org/irp /congress/2004_cr/s012804b.html.

The Runnymede Trust. "Islamophobia a Challenge for Us All", laman sesawang RunnymedeTrust. Dicapai 15 April 2019, http:// www.runnymedetrust.org/uploads/publications/pdfs/islamophob ia.pdf. 
Uenal, Fateh. "Disentangling Islamophobia: The Differential Effects of Symbolics, Realistic, and Terroristic Threat Perceptions as Mediators between Social Dominance Orientation and Islamophobia." Journal of Social and Political Psychology, Vol.4 (1) (2016), 6.

Zakir Husain. "Islam and the Modern Age." Journal Islam and the Modern Age, volume xxxix, no. 3 (Ogos 2008), 80. 